\title{
THE BLUEING OF AMERICA: THE BRIDGE BETWEEN THE WAR ON DRUGS AND THE WAR ON TERRORISM
}

\author{
Gerald G. Ashdown ${ }^{*}$
}

\section{INTRODUCTION}

The reaction to the Vietnam War protest years, the presidency of Richard Nixon, and ultimately that of Ronald Reagan, ushered in a conservative revolution in the United States that still endures. Republican Presidents during this period have appointed eleven Justices to the United States Supreme Court, ${ }^{1}$ seven of whom serve on the Court today. ${ }^{2}$ Coinciding with this historical phenomenon was the proliferation of drug usage in the country: first marijuana, hallucinogenic drugs, and amphetamines during the counterculture years of the late ' $60 \mathrm{~s}$ and ' $70 \mathrm{~s}$, and later powder and then crack cocaine. When prosecutorial emphasis shifted, especially at the federal level, ${ }^{3}$ to meet the increased fascination with narcotics, courts in the country became deluged with drug cases, many if not most of which presented Fourth Amendment search and seizure issues. This, of course, was because the Fourth Amendment's exclusionary rule could make the corpus of the crime unavailable to the prosecution. ${ }^{4}$

Due to the presence of this important Fourth Amendment issue in drug prosecutions, both state and federal, a significant number of these cases found their way to the United States Supreme Court for review. In most of these cases, the Court did not disappoint the Republican Presidents who had appointed a majority of the Justices. Under the tutelage of Chief Justices

\footnotetext{
* James A. "Buck" \& June M. Harless Professor of Law, West Virginia University College of Law.

1. Justices Blackmun, Powell, and Rehnquist were appointed by Richard M. Nixon. Justice Stevens was appointed by Gerald Ford. Justices O'Connor, Scalia, and Kennedy were appointed by Ronald Reagan. Justices Souter and Thomas were appointed by George H.W. Bush. George W. Bush recently appointed Chief Justice Roberts and Justice Samuel Alito, which makes twelve.

2. Justices Stevens, Scalia, Kennedy, Souter, Thomas, Roberts (C.J.), and Alito.

3. See generally Gerald G. A shdown, Federalism, Federalization, and the Politics of Crime, $98 \mathrm{~W}$. VA. L. REV. 789 (1996); Wayne R. LaFave, The “Routine Traffic Stop" From Start to Fin ish: Too Much "Routine," Not Enough Fourth Amendment, 102 MICH. L. REV. 1843 (2004); Stephen A. Saltzburg, Lecture, The Supreme Court, Criminal Procedure and Judicial Integrity, 40 AM. CRIM. L. REV. 133 (2003); Stephen F. Smith, The Rehnquist Court and Criminal Procedure, 73 U. COLO. L. REV. 1337 (2002).

4. $\quad$ See Mapp v. Ohio, 367 U.S. 643 (1961).
} 
Burger and Rehnquist, the Court took the opportunity to rule in favor of the government most of the time, lending its imprimatur to the particular search and seizure practice employed and, in doing so, slanted the Constitution toward validating police practices and away from individual privacy-what I have called the "blueing" (for police blue) of America. Not only was the warrant requirement relaxed, ${ }^{5}$ but also expectations of privacy were drastically narrowed, ${ }^{6}$ and the police were granted virtually open season on vehicle searches. ${ }^{7}$ The definition of probable cause was diluted ${ }^{8}$ and the standards on what constituted a law enforcement search ${ }^{9}$ or seizure ${ }^{10}$ were drawn narrowly.

During this time, the Court also has been relaxing the rules on interrogation surrounding Miranda $v$. Arizona. ${ }^{11}$ Interrogation is largely superfluous in drug cases because the possession of drugs makes interrogation unnecessary, and, conversely, because suppression of illegally seized narcotics makes any admission irrelevant (due either to the fruit of the poisonous tree doctrine or lack of the corpus of the crime). Nevertheless, the parallel between the Supreme Court's Fourth and Fifth Amendment jurisprudence is squarely indicative of the bent to the law enforcement side of the ledger; a swing to the crime control model.

In the 1960s, Herbert Packer described what he called the "Two Models of the Criminal Process." 12 Whereas, "[t]he value system that underlies the Crime Control Model is based on the proposition that the repression of criminal conduct is by far the most important function to be performed by the criminal process,"13 the "Due Process Model" stresses individual rights,

5. See infra notes $30-68$ and accompanying text.

6. See infra notes 48-68 and accompanying text.

7. See infra notes 91-151 and accom panying text.

8. See infra notes 30-39 and accom panying text.

9. See infra notes $69-72$ and accompanying text.

10. See infra notes $74-90$ and accompanying text.

11. 384 U.S. 436 (1966). See, e.g., Pennsylvania v. Muniz, 496 U.S. 582 (1990) (establishing the "booking exception" to Miranda requirements); Illinois v. Perkins, 496 U.S. 292 (1990) (finding that interrogation in the Miranda context did not include conversations with undercover agents because the "essential ingredients of a police-dominated atmosphere and compulsion [were] not present"); Arizona v. Mauro, 481 U.S. 520 (1987) (finding no "interrogation" by the police in allowing the wife of an in-custody suspect to speak with the suspect in the presence of police); New York v. Quarles, 467 U.S. 649 (1984) (establishing the public safety exception); California v. Beheler, 463 U.S 1121 (1983) (per curiam) (finding that questioning at a police station was not custodial); Rhode Island v. Innis, 446 U.S. 291 (1980) (finding no interrogation when a custodial suspect responded to a comment from on e officer to another).

12. HeRbert L. PACKER, THE Limits OF THE CRIMINAL SANCTION 149-246 (1968) [hereinafter Limits of THE CRIMINAL SANCTION]; Herbert L. Packer, Two Models of the Criminal Process, 113 U. PA. L. REV. 1 (1964).

13. LIMITS OF THE CRIMINAL SANCTION, supra note 12 , at 158. 
equality, and limitation on official power. ${ }^{14}$ By the end of the 1960 s, the Warren Court was in the final stages of fostering the "Due Process Model" by constitutionalizing criminal procedure. This was accomplished both by giving content to the general provisions in the Bill of Rights dealing with criminal procedure, and by completing the process of selectively applying the Bill of Rights to the states through the Fourteenth Amendment, all designed to protect the individual rights of criminal defendants. It is possible to view the Burger and later Rehnquist Courts as reacting to the individual and civil rights focus of the Warren years, a correction if you wish. Nonetheless, there has been a drastic swing on the Court toward the "Crime Control Model." Considerable privacy interests and civil liberties were sacrificed to law enforcement during the last three decades of the twentieth century in the name of the war on drugs. To grasp the point, it only needs to be realized that the Supreme Court has held that there is no expectation of privacy in personal bank records,$^{15}$ or one's garbage, ${ }^{16}$ or in private conversations, ${ }^{17}$ and that being confronted by a cop with a holstered gun on a bus does not amount to a seizure. ${ }^{18}$

My contention is straightforward. Well before the twenty-first century, the 9/11/01 terrorist attacks on the World Trade Center and the Pentagon, and the resulting War on Terror, the country and Supreme Court already had been fighting another war for thirty years - the so-called "War on Drugs"- and it was every bit as devastating to civil liberties, although slower and more methodical, than our new "W ar on Terror" promises to be.

After the devastating attacks of September 11, 2001, we now have the Department of Homeland Security and the USA PATRIOT Act. ${ }^{19}$ In addition to the prolonged detention of persons, obliquely labeled "enemy combatants," without lawyers or any kind of due process, ${ }^{20}$ the PATRIOT Act has brought,

14. Id. at $165-70$.

15. See United States v. Miller, 425 U.S. 435 (1976) (holding no expectation of privacy in bank records subpoenaed from depositor's bank); see also Couch v. United States, 409 U.S. 322 (1973) (stating no privacy interest involved in the summons of business records from taxpayer's accountant).

16. See California v. Greenwood, 486 U.S. 35 (1988) (holding no expectation of privacy in personal garbage left at the curb for collection).

17. See United States v. White, 401 U.S. 745 (1971) (holding no legitimate expectation of privacy in personal conversations with another).

18. See United States v. Drayton, 536 U.S. 194 (2002) (holding no seizure when officers patted down bus passengers with permission); Florida v. Bostick, 501 U.S. 429 (1991) (holding no seizure when police searched luggage on a bus).

19. Uniting and Strengthening America by Providing Appropriate Tools Required to Intercept and Obstruct Terrorism Act of 2001, Pub. L. No. 107-56, 115 Stat. 272 [hereinafter USA PATRIOT Act] (codified as amended in scattered sections of $12,15,18$ and 31 U.S.C.).

20. Rum sfeld v. Padilla, 124 S. Ct. 2711 (2004); Hamdi v. Rum sfeld, 124 S. Ct. 2633 (2004). 
among other things, sneak-and-peek ${ }^{21}$ and nationwide search warrants, ${ }^{22}$ roving wiretaps, ${ }^{23}$ surveillance of computer communication, ${ }^{24}$ application of streamlined foreign intelligence surveillance procedures to domestic criminal investigations, ${ }^{25}$ and perusal of library and book records. ${ }^{26}$ Still worse, we are utilizing torture to interrogate detainees, which is apparently authorized at the highest levels of the U.S government. ${ }^{27}$

As the country has meandered to the right politically in the past thirty to thirty-five years, a steady deterioration of privacy protection and civil liberties has developed. First, methodically and largely unnoticed in the name of the War on Drugs, and now more rapidly and apparent in the War on Terrorism, our free, open society is casually losing its grip. It is, of course, no answer to say that this was demanded by the terrorist threat since much of it occurred prior to the events of September 11, 2001, through creeping constitutional lawmaking involving purely domestic law enforcement. Nor is it an answer to argue that the more recent incarnation of the threat to civil liberties is merely directed at investigations of terrorists. The PATRIOT Act has now been reauthorized, circumventing its original sunset provisions, and to assume that the tools provided by this statute will not be applied in investigations of domestic crime is, at best, wishful thinking.

\footnotetext{
21. See infra notes 227-54 and accompanying text.

22. See infra notes $255-58$ and accompanying text.

23. See infra notes $280-88$ and accompanying text.

24. See infra notes $305-08$ and accompanying text.

25. See infra notes $260-98$ and accom panying text.

26. See infra notes 309-30 and accom panying text.

27. See generally Dana Priest, Justice Dept. Memo Says Torture 'May Be Justified', WASHINGTONPOST.COM, June 13, 2004, http:/www.washingtonpost.com/wp-dyn/articles/A388942004 Jun13.htm 1; Mem orandum from Jay S. Bybee, Assistant Attorney General, U.S. Department of Justice Office of Legal Counsel, to Alberto R. Gonzales, Counsel to the President (Aug. 1, 2002) (on file with author) (discussing the application of 18 U.S.C. $\S \S 2340-2340 \mathrm{~A}(2000)$ ). The Torture M emo is not the only recent controversial memo from the Department of Justice Office of Legal Counsel. A January 22, 2002 memo, for example, argued that the Geneva Convention does not apply to enemy combatants. See Memorandum from Jay S. Bybee, U.S. Department of Justice Office of Legal Counsel, to Alberto R. Gonzales, Counsel to the President, and William J. Haynes II, General Counsel, Department of Defense (Jan. 22, 2002) (on file with author) (discussing the application of treaties and laws to al Qaeda and Taliban detainees).
} 


\section{THE WAR ON DRUGS}

I have no intention of re-analyzing all of the Fourth Amendment decisions of the United States Supreme Court which have limited the protection of that provision. That has already been done by many, ${ }^{28}$ including me. ${ }^{29}$ The decisions are many and profound, and they have virtually all come in drug cases. To provide a flavor for the restrictions on personal privacy, however, I do want to survey a few of the decisional areas favoring law enforcement search and seizure practices to illustrate the threat to civil liberties antedating the advent of the War on Terror. I do this principally to emphasize that the currently perceived assault on our personal freedoms began thirty years ago in the War on Drugs and only recently has been exacerbated by the slide into the fight against terrorism.

\section{A. Probable Cause, the Good Faith Exception, and the Deterrent Effect of the Exclusionary Rule}

Beginning in 1959 in Draper $v$. United States ${ }^{30}$ and lasting for nearly twenty-five years, the United States Supreme Court developed a precise set of rules for a magistrate to follow to measure whether information provided by a government informant established probable cause for the issuance of a search warrant. These rules required that the affidavit provide information indicating: (1) the informant's basis of knowledge, i.e., how the information about the criminal activity was acquired, and (2) the informant's veracity or why the information was likely reliable. ${ }^{31}$ Fairly viewed, if either of these requirements were not met, they could be supplanted by the informant providing sufficient detail about the criminal activity which could be corroborated by law enforcement officials. ${ }^{32}$ The Court rejected a "totality of circumstances" approach in favor of a more precise analysis to ensure both the actual existence

\footnotetext{
28. See, e.g., Brian J. Serr, Great Expectations of Privacy: A New Model for Fourth Amendment Protection, 73 MINN. L. REV. 583 (1989); James J. Tom kovicz, Beyond Secrecy for Secrecy's Sake: Toward an Expanded Vision of the Fourth Amendment Privacy Province, 36 HASTINGS L.J. 645 (1985).

29. Gerald G. Ashdown, The Fourth Amendment and the "Legitimate Expectation of Privacy", 34 VAND. L. REV. 1289 (1981).

30. 358 U.S. 307 (1959).

31. See Spinelli v. United States, 393 U.S. 410, 412-13 (1969).

32. See Draper, 358 U.S. at 309 \& n.2. The informant's basis of knowledge was not provided, but the Court held that probable cause was established because officers verified the detailed description of Draper, and information that he would return to Denver from Chicago on one of two days, that he would be wearing a light-colored raincoat, brown slacks, and black shoes, and would be walking "real fast." Id.
} 
of an informant and to provide standards for magistrates to apply in making the probable cause determination. ${ }^{33}$

In 1983 in Illinois v. Gates, after nearly a quarter of a century with these guidelines, the Supreme Court per then Justice Rehnquist threw them out in favor of the same totality of circumstances test the Court earlier had rejected consistently. ${ }^{34}$ Although magistrates had been applying the standards for years, the majority concluded that they were too complicated and confusing and that, in applying the totality approach,

[t]he task of the issuing magistrate is simply to make a practical, common-sense decision whether, given all the circumstances set forth in the affidavit before him, including the "veracity" and "basis of knowledge" of persons supplying hearsay information, there is a fair probability that contraband or evidence of a crime will be found in a particular place. $^{35}$

Justice Rehnquist then said, "And the duty of a reviewing court is simply to ensure that the magistrate had a 'substantial basis for . . . conclud[ing]' that probable cause existed." ${ }^{36}$ In other words, by the time the probable cause determination is reviewed in a motion to suppress or on appeal, the standard is whether there was a substantial basis for a fair probability that evidence of crime would be found. ${ }^{37}$

This accomplishes at least two things, both reducing Fourth Amendment protections in favor of law enforcement. First, and more specifically, the new standard allowed probable cause to be established from anonymous tips, like the one provided in the Gates case itself. ${ }^{38}$ Under the former basis of

33. Spinelli, 393 U.S. at 415.

34. See Illinois v. Gates, 462 U.S. 213 (1983).

35. Id. at 238 .

36. Id. at 238-39.

37. Id. at 238-39 (quoting Jones v. United States, 362 U.S. 257, 271 (1960)).

38. The tip in Gates was received by way of anonymous letter to the Bloomingdale, Illinois police department. It stated:

This letter is to inform you that you have a couple in your town who strictly make their living on selling drugs. They are Sue and Lance Gates, they live on Greenway, off Bloomingdale Rd. in the condominiums. Most of their buys are done in Florida. Sue his wife drives their car to Florida, where she leaves it to be loaded up with drugs, then Lance flys [sic] down and drives it back. Sue flys [sic] back after she drops the car off in Florida. May 3 she is driving down there again and Lance will be flying down in a few days to drive it back. At the time Lance drives the car back he has the trunk loaded with over $\$ 100,000.00$ in drugs. Presently they have over $\$ 100,000.00$ worth of drugs in their basement.

They brag about the fact they never have to work, and make their entire living on pushers.

I guarante e if you watch them carefully you will make a big catch. They are friends with some big drug[] dealers, who visit their house often. 
knowledge and veracity requirements, the latter could never be satisfied directly because the identity of the informant is inherently unknown. Second, and more generally, the totality standard articulated in Gates is so vague and flexible, and the standard of review so deferential, that it seems virtually impossible to challenge the finding of probable cause, unless there is a bare bones affidavit ${ }^{39}$ in a warrant application (which could only be a result of poor police work). Although Gates involved a search warrant, there is nothing in the opinion that limits the standard for probable cause to warrant cases, exacerbating the problem by permitting embellishment and hindsight judgment in non-warrant cases.

A year later in United States v. Leon, ${ }^{40}$ the Supreme Court adopted in warrant cases the good faith exception to the exclusionary rule, primarily based on the Court's exclusive focus on the rule's deterrent effect on law enforcement. ${ }^{41}$ The good faith exception not only independently undermines Fourth Amendment standards for warrants, but also when combined with the loose definition of probable cause from Gates, it makes the probable cause basis for a warrant virtually immune from challenge. In fact, the malleable definition of probable cause from Gates actually makes that decision a kind of good faith standard even in the case of warrantless searches.

The exclusive focus on the deterrent impact of the exclusionary rule-as opposed to the interest in judicial integrity-has been relied upon by the Court in a number of cases to restrict the operation of the rule. In United States $v$. Calandra, a majority of the Court held the exclusionary rule inapplicable to grand jury proceedings. ${ }^{42}$ Two years later, a majority held the rule inapplicable to a civil tax enforcement proceeding ${ }^{43}$ and inapplicable on federal habeas corpus review of a state conviction if the state had provided a full and fair opportunity to raise the Fourth Amendment issue. ${ }^{44}$ Subsequently,

\footnotetext{
Lance \& Susan Gates

Greenway

in Condominiums

Id. at 225 .

39. See Aguilar v. Texas, 378 U.S. 108, 109 (1964), in which the affidavit of police officers swore only that they had "received reliable information from a credible person and do believe" that narcotics were in the described premises.

40. 468 U.S. 897 (1984).

41. Id. at $918-21$.

42. 414 U.S. 338 (1974).

43. See United States v. Janis, 428 U.S. 433 (1976).

44. See Stone v. Powell, 428 U.S. 465 (1976).
} 
the Court held that the rule also would not apply in a civil deportation hearing ${ }^{45}$ and parole revocation proceedings. ${ }^{46}$

In all of these cases, the principal foundation for the position of the majority was that to the extent the exclusionary rule deters officers from violating the Fourth Amendment, the focus of the law enforcement mindset is on the introduction of evidence at the criminal trial and on appeal; tangential proceedings are not seriously considered by law enforcement officials in the deterrent equation. This, of course, ignores both the incremental deterrent effect that application of the rule to all proceedings would have and the interest in judicial integrity - the notion that governmental processes which impose severe disabilities on individuals should not benefit from their own violation of the law. ${ }^{47}$

Taken together, focusing only on the deterrent impact of the exclusion of evidence, diluting the standard for probable cause, and creating the good faith exception to the exclusionary rule provides a clear guide to where the Court was headed with Fourth Amendment law during the last quarter of the twentieth century. The War on Drugs was being fought at the expense of personal freedoms. The effect was subtle, but substantial when viewed in the conglomerate, as the next sections will show.

\section{B. The Legitimate Expectation of Privacy}

In 1967, in Katz v. United States, the United States Supreme Court in an opinion by Justice Stewart changed the focus of the Fourth Amendment from a property-and-trespass rationale (whether there was an intrusion into a "constitutionally protected area") to instead view it through a privacy lens. ${ }^{48}$ In $K a t z$, no trespass into a protected property interest had taken place because government agents had placed the electronic bug involved on the outside of a public telephone booth. ${ }^{49}$ The change from the narrower property to a broader privacy rationale signaled an expansion of Fourth Amendment protection. Just four years later, United States $v$. White $e^{50}$ was a harbinger that it was not to be.

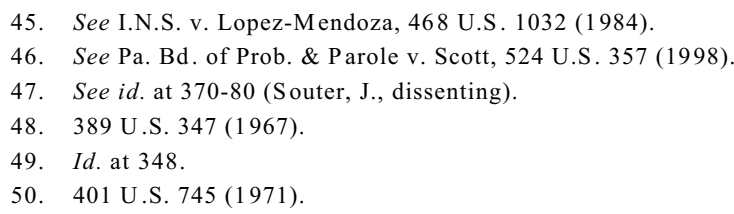


White was a classic wired informant case of the kind the Court formerly had permitted under the no trespass and assumption of the risk rationales. ${ }^{51}$ $K a t z$, how ever, had clearly undermined the lack of trespass justification for the earlier decisions, and the assumption of the risk theory was also on shaky ground under the Katz expectation of privacy analysis. Justice White's plurality opinion was able to finesse the problem by utilizing Justice Harlan's concurring opinion from Katz itself. In Katz, Justice Harlan wrote that not only must a suspect have a subjective expectation of privacy-something that the defendant White surely had in his private conversation with the informant - but also it had to be an expectation that society was prepared to recognize as objectively reasonable. ${ }^{52}$ Justice White argued in the White case:

Our problem is not what the privacy expectations of particular defendants in particular situations may be or the extent to which they may have in fact relied on the discretion of their companions. Very probably, individual defendants neither know nor suspect that their colleagues have gone or will go to the police or are carrying recorders or transmitters. Otherwise, conversation would cease and our problem with these encounters would be nonexistent or far different from those now before us. Our problem, in terms of the principles announced in Katz, is what expectations of privacy are constitutionally "justifiable" - what expectations the Fourth Amendment will protect in the absence of a warrant. ${ }^{53}$

Thus the ground had been laid for a narrow view of privacy expectations. To be recognized, an expectation of privacy had to be "constitutionally "justifiable", or what was to become in later cases a "legitimate expectation of privacy," as recognized not necessarily by society, but by the Court as its proxy. ${ }^{54}$ Even Justice Harlan, the author of the concurring opinion in Katz on which Justice White relied, dissented in White in some of the most eloquent language to be found in a Supreme Court opinion. ${ }^{55}$ It requires emphasis - and this is crucial - that when the Court concludes there is no expectation of privacy, the Fourth Amendment simply does not apply, which in turn means

51. See, e.g., On Lee v. United States, 343 U.S. 747 (1970) (rejecting the argument that the wired informant was a trespasser because consent to entry was based on fraud); Lewis v. United States, 385 U.S. 206 (1966) (holding that the federal agent's entry into defendant's residence by adopting the guise of “Jimmy the Pollack" w as not a trespass); see also Hoffa v. United States, 385 U.S. 293 (1966) (holding that the risk of being overheard or betrayed is an inherent condition of human society and thus the kind of risk people assume whenever they speak); Lopez v. United States, 373 U.S. 427, 439 (1963) (holding that the petitioner assumed the risk that his bribe offer to another would be accurately reproduced in court, "whether by faultless memory or mechanical recording").

52. Katz, 389 U.S. at 361 (Harlan, J., concurring).

53. White, $401 \mathrm{U} . \mathrm{S}$. at 751-52.

54. Id.; see infra notes 59-67 and accompanying text.

55. See White, 401 U.S. at 768, 795 (Harlan, J., dissenting). 
that law enforcement needs no justification whatsoever (no warrant, no probable cause, not even suspicion) for the particular investigatory practice employed. ${ }^{56}$ As argued by Justice Harlan's dissent, applying the Fourth Amendment to electronic eavesdropping does not end the practice. ${ }^{57} \mathrm{He}$ stated, "[I]t is too easy to forget—and, hence, too often forgotten - that the issue here is whether to interpose a search warrant procedure between law enforcement agencies engaging in electronic eavesdropping and the public generally." 58

It was not long after White until the ill-fated decision in United States v. Miller. ${ }^{59}$ In Miller, the Court followed the implications of White, and held that a person has no legitimate expectation of privacy in personal financial information voluntarily provided to a bank since the depositor assumes the risk that the third-party bank will disclose the records to the government. ${ }^{60}$ The defendant thus had no protected Fourth Amendment interest that the records would be shielded from a subpoena directed to the bank. ${ }^{61}$ Although this surprising conclusion was overturned by Congress, ${ }^{62}$ it set the foundation for the ruling six years later in Smith v. Maryland ${ }^{63}$ that by voluntarily disclosing numbers dialed from a telephone to the telephone company, the caller has no legitimate expectation of privacy in these numbers recorded by a pen register device installed by or at the behest of the police. ${ }^{64}$

White, Miller, and Smith were followed by decisions in the '80s which concluded that there were no legitimate expectations of privacy in a farm field,${ }^{65}$ in the airspace above a dwelling,${ }^{66}$ or in personal garbage placed at the

56. Id. Many of my criminal procedure students are shocked when they learn of this particular jurisprudence.

57. White, 401 U.S. at 788 (Harlan, J., dissenting).

58. Id. at 788 .

59. 425 U.S. 435 (1976).

60. Id. at $442-43$.

61. Id. at 444 .

62. See 12 U.S.C. $\$ \$ 3401-3422$ (2000) (enacted Nov. 10,1978). This statu te is known as the "Right to Financial Privacy Act."

63. 442 U.S. 735 (1979).

64. Id. at 741-46.

65. United States v. Oliver, 466 U.S. 170, 179 (1984) ("[O]pen fields do not provide the setting for those intimate activities that the Amendment is intended to shelter from government interference or surveillance. There is no societal interest in protecting the privacy of those activities, such as the cultivation of crops, that occur in open fields. Moreover, as a practical matter these lands usually are accessible to the public and the police in ways that a home, an office, or commercial structure would not be.").

66. California v. Ciraolo, 476 U.S. 207, 213-14 (1986) (noting that where an aircraft was flying at an altitude of 1000 feet, "[a]ny member of the public flying in this airspace who glanced down could have seen everything that these officers observed"); see Florida v. Riley, 488 U.S. 445 (1989) (holding that a 
curb for collection. ${ }^{67}$ It required a case involving the home ${ }^{68}$ to break the trend of cases refusing to find expectations of privacy and Fourth Amendment protection. The effect of these cases on privacy interests is profound. Finding a privacy right and applying the Fourth Amendment would not place these areas beyond the reach of law enforcement. It would simply require some justification-at least suspicion, possibly probable cause, and maybe a warrant-for the invasion. As it stands, no justification of any sort is required in instances where the Court has found no objectively reasonable expectation of privacy to exist. Quite literally, a wired informant could be placed anywhere, anytime, with any person or group without the slightest justification for doing so beyond government whim. The war on privacy - in the name of the War on Drugs - was well underway long before the W ar on Terror.

\section{No Search or Seizure}

Jurisprudentially paralleling the Supreme Court's no privacy decisions are the cases where the Court found no search or no seizure to have taken place, a conclusion which likewise avoids any Fourth Amendment requirements. In United States v. Knotts, ${ }^{69}$ the Supreme Court concluded that the tracking of an electronic beeper placed in a package and transported in the suspect's automobile did not constitute a Fourth Amendment search because it did nothing that visual surveillance could not accomplish. ${ }^{70}$ During the same term, the Court held that the use of a drug-sniffing dog to detect the presence of narcotics in luggage located in a public place did not constitute a search. ${ }^{71}$ Although Justice O'Connor's majority opinion in United States v. Place declared "that a person possesses a privacy interest in the contents of personal luggage that is protected by the Fourth Amendment,"72 a canine sniff is a limited investigative procedure because it does not require opening the luggage

\footnotetext{
helicopter 400 feet above a partially covered greenhouse in a residential backyard did not violate any law or regulation)

67. California v. Greenwood, 486 U.S. 35, 40 (1988) (holding that an individual expectation of privacy must be objectively reasonable; here, "respondents exposed their garbage to the public sufficiently to defeat their claim to Fourth Amendment protection").

68. Kyllo v. United States, 533 U.S. 27 (2001) (holding that thermal imaging device detecting heat emanating from a home was an unlaw ful search).

69. 460 U.S. 276 (1983).

70. Id. at 277, 285. But see United States v. Karo, 468 U.S. 705, 723 (1984) (tracking a beeper installed in a container inside a home implicates the Fourth Amendment and requires a search warrant)

71. United States v. Place, 462 U.S. 696 (1983).

72. Id. at 707
} 
and reveals only the presence of contraband. ${ }^{73}$ This decision, of course, opened the use of drug-sniffing $\operatorname{dog} s$ to every place from airports to automobiles to schools; the only thing left protected was the home. Any other item arguably in public was vulnerable to the drug dog; no suspicion was required because it was not a search. This "no search" casualty to privacy in the War on Drugs has tremendous potential for application to video surveillance and new surveillance devices such as weapons detectors, and facial and vehicle character recognition technology.

A doctrinal development equally threatening to personal privacy is the Court's "no seizure" theory. This concept developed from cases involving the so-called "drug courier profile," a set of otherwise innocent behavior patterns which, when taken together, allegedly give the well-trained law enforcement officer suspicion to stop a person for further investigation. ${ }^{74}$ While grappling with the issue of whether the factors in the profile provided the necessary reasonable suspicion for a Terry-type stop, the Court eventually came up with its "no seizure" rationale. ${ }^{75}$ This is the notion that no Fourth Amendment seizure takes place when an officer confronts an individual, asks questions, asks for identification, and even for permission to search, unless a reasonable person would feel that they were not free to leave. ${ }^{76}$ This rule is largely a non sequitur; very few persons stopped and questioned by law enforcement personnel with badges and guns would believe they were free to leave. It was, nonetheless, a way for the Court to circumvent the reasonable suspicion requirement, because if there is no seizure, then no suspicion is required.

This permissive encounter rule was later moved from the air terminal and the workplace to investigative procedures on buses, where officers with insignia and visible weapons would board buses during scheduled stops and, without articulable suspicion, ask particular passengers for their identification and ticket and permission to search their person and luggage. ${ }^{77}$ When confronted with the claim that a passenger in the confines of a bus in the midst of a journey would not feel free to leave, Justice O'Connor's majority opinion in Florida v. Bostick responded that the defendant had voluntarily placed himself in the bus independent of police conduct, and that "[i]n such a

73. Id.

74. See, e.g., United States v. Sokolow, 490 U.S. 1, 10 (1989); Florida v. Royer, 460 U.S. 491, 501 (1983); United States v. Mendenhall, 446 U.S. 544, 562 (1980).

75. See Florida v. Bostick, 501 U.S. 429, 434 (1991).

76. See, e.g., United States v. Drayton, 536 U.S. 194 (2002); Florida v. Bostick, 501 U.S. 429 (1991); I.N.S. v. Delgado, 466 U.S. 210 (1984); United States v. Mendenhall, 446 U.S. 544 (1980).

77. See United States v. Drayton, 536 U.S. 194 (2002); Florida v. Bostick, 501 U.S. 429 (1991). 
situation, the appropriate inquiry is whether a reasonable person would feel free to decline the officers' requests or otherwise terminate the encounter." 78 Although remanding the case for determination of whether a seizure occurred under this standard, Justice O'Connor noted that "the facts . . indicate that the officers did not point guns at Bostick or otherwise threaten him and that they specifically advised Bostick that he could refuse consent."79 In other words, he had not been arrested, but that never before had been necessary in order to constitute a Fourth Amendment seizure under the Terry v. Ohio line of cases, which require reasonable suspicion for the stop.

Likewise, in United States $v$. Drayton, where three officers took over a bus during a scheduled stop, and admittedly gave no warning of a right to refuse cooperation, a 6-3 majority still concluded that confronting Drayton and requesting permission to search, first his luggage and then his person, did not amount to a seizure. ${ }^{80}$ In fact, Justice Kennedy stated for the majority that the presence of other passengers would make a reasonable person feel even more secure in a decision not to cooperate than in other circumstances (none of course did so). ${ }^{81}$ Indeed, Justice Kennedy's narrow definition of a seizure, ${ }^{82}$ paralleling that of Justice O'Connor in Bostick, made it sound as though a seizure would occur only if there is an actual arrest, again seemingly contradicting a long line of Terry $v$. Ohio stop-and-frisk precedent. ${ }^{83}$ To reiterate, the significance of the "no seizure" rule, like the "no search" rule, is that if no seizure has occurred, no Fourth Amendment justification for the encounter is necessary. As in the airport or bus cases, it can be based on standardless suspicion or whim.

The virtual collapse of the Terry stop-and-frisk seizure regime into a noseizure/arrest dichotomy is also exemplified by the Supreme Court's holding in California v. Hodari D. ${ }^{84}$ where the juvenile suspect dropped a small rock of crack cocaine while running from a police officer. ${ }^{85}$ Since no probable cause or suspicion existed at the time the officer gave chase to the fleeing suspect, the issue was whether Hodari had been seized by the chase. ${ }^{86}$ Hodari

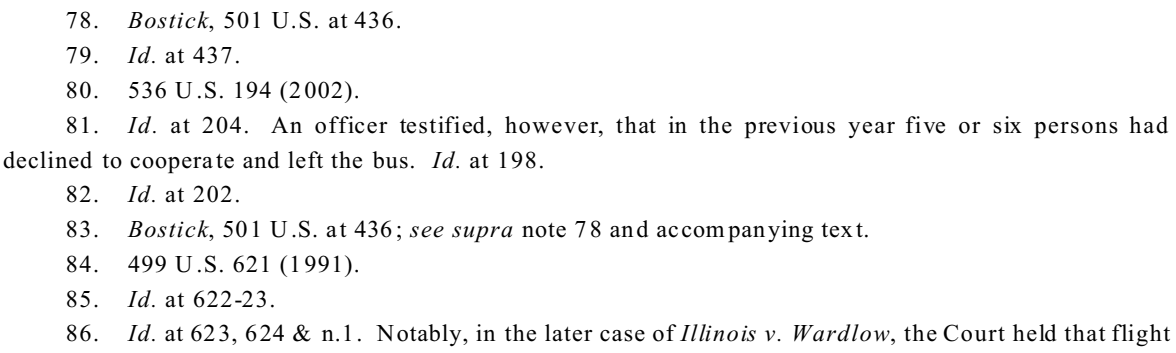


contended that the officer's pursuit amounted to a show of authority restraining his liberty and qualified as a seizure. ${ }^{87}$ Justice Scalia's majority opinion disagreed, suggesting that the Fourth Amendment could not be stretched beyond the meaning of arrest ${ }^{88}$ and concluding that "[a]n arrest requires either physical force ... or, where that is absent, submission to the assertion of authority." ${ }^{89}$ This clearly suggests that anything short of an arrest (as defined above) does not amount to a seizure. Consequently, no Fourth Amendment justification for the encounter is necessary. Although Terry is not entirely a dead letter, ${ }^{90}$ especially where a weapons frisk takes place, the no seizure cases provide law enforcement substantial leeway to stop and question (and search with permission) individuals without satisfying any Fourth Amendment seizure standards - largely another response to the War on Drugs.

D. Vehicles

\section{The Automobile Exception}

Any discussion of the escalation of permissible police search and seizure practices, and the concomitant loss of civil liberties, would be woefully incomplete without a reference to vehicles (and the drugs found inside them). Although an automobile exception to the warrant requirement-a search of a vehicle supported by probable cause does not require a warrant-has been around a long time, ${ }^{91}$ it has expanded with a vengeance during the War on Drugs. ${ }^{92}$ Originally based on the concept of exigent circumstances (the inherent mobility of an automobile), the lack of the need for a warrant rather easily slid into the Court's privacy analysis. ${ }^{93}$ The need to change theories was caused by the fact that in many cases the car was going nowhere; it had been completely immobilized by the police, often by impoundment, before it was

\footnotetext{
itself, along with other factors, could create the requisite reasonable suspicion necessary for a Terry seizure. 528 U.S. $119,124(2000)$

87. Hodari D., 499 U.S. at 625.

88. Id. at 627 .

89. Id. at 626

90. See Hiibel v. Sixth Judicial Dist. Court, 542 U.S. 177 (2004) (holding that a state law requiring an individual to identify himself during a Terry stop does not violate the Fourth or Fifth Amendments); United States v. Sharpe, 470 U.S. 675 (1985) (holding that a 20-minute roadside detention was a justifiable Terry investigative stop under the circumstances presented).

91. See Carroll v. United States, 267 U.S. 132 (1925).

92. See infra notes $105-21$ and accompanying text.

93. See infra notes 100-02 and accompanying text.
} 
searched..$^{94}$ Thus, the Court seized on a second justification for dispensing with the warrant requirement - the diminished expectation of privacy in an automobile. ${ }^{95}$ This reduced expectation is justified by the fact that vehicles travel in public in plain view and are pervasively regulated by the government. ${ }^{96}$ This conclusion, that one has a diminished expectation of privacy in a vehicle, itself of questionable validity based on subjective (and reasonable) privacy expectations, has not been limited. It has been applied to motor homes, ${ }^{97}$ and has been expanded to apply to every container placed in a vehicle, ${ }^{98}$ including luggage, regardless of the privacy interest in the item outside the vehicle, and irrespective of to whom it belongs. ${ }^{99}$

The Court has consistently held that luggage and other repositories of personal effects are entitled to a legitimate privacy expectation, which absent exigent circumstances requires both probable cause and a warrant to search. ${ }^{100}$ Initially, this conclusion held true regardless of whether such a closed container was placed in a vehicle. ${ }^{101}$ However, a distinction soon developed between the situation where probable cause focused on a container placed in an automobile, and one where there was probable cause to search a vehicle which happened to house a container; a warrantless search of the container was permitted in the latter case under the vehicular exception. ${ }^{102}$ Eventually, because this distinction created "confusion for law enforcement officers," it was abandoned in California v. Acevedo in favor of a clear rule that authorized the warrantless search of all containers in vehicles, irrespective of whether the investigation had focused on the container before it was placed in the car. ${ }^{103}$ In Acevedo there was probable cause to believe that a package wrapped in a brown paper bag contained marijuana before it was placed in the trunk of

94. See Florida v. Myers, 466 U.S. 380 (1984) (car impounded and stored in a secure area); Cham bers v. Maroney, 399 U.S. 42 (1970) (occupants arrested and automobile driven to police station).

95. California v. Carney, 471 U.S. 386, 391 (1986).

96. See id. at 391-92 (sum marizing cases).

97. Id. at 388-89.

98. United States v. Ross, 456 U.S. 798, 821 (1982).

99. Wyoming v. Houghton, 526 U.S. 295, 301 (1999).

100. See Arkansas v. Sanders, 442 U.S. 753 (1979), overruled by California v. Acevedo, 500 U.S. 565 (1991).

101. See Arkansas v. Sanders, 442 U.S. 753 (1979) (holding that the search of luggage seized from the trunk of a taxi was unlawful even though the police had probable cause to believe it contained marijuana); United States v. Chadwick, 433 U.S. 1 (1977) (holding that the warrantless search was unreasonable even though the officers had probable cause to believe the footlocker, placed in the trunk of an automobile, contained marijuana).

102. See United States v. Ross, 456 U.S. 798 (1982) (holding that a probable cause se arch of a vehicle extends to all containers found within; here, a brown paper bag found in the trunk).

103. Acevedo, 500 U.S. at 577,580 . 
defendant's car. ${ }^{104}$ As pointed out by Justice Stevens's dissent, the majority created the curious paradox of providing full Fourth Amendment protection to a briefcase carried on the street (requiring both probable cause and a warrant), but once this same briefcase was placed in an automobile it lost the constitutional protection of the warrant requirement. ${ }^{105}$ It comes as no surprise that all of the cases leading to the ultimate development of this rule involved narcotics, as do virtually all of the cases discussed herein dealing with the War on Drugs.

The most recent step in the steady progression of the automobile exception came in Wyoming v. Houghton where, in the case of a vehicle stopped for speeding, the majority permitted the search of a purse belonging to a passenger despite the absence of probable cause. ${ }^{106}$ Probable cause to search focused on the driver, who had admitted that a syringe visible in his shirt pocket was used to take drugs. ${ }^{107}$ Much earlier, in Rakas v. Illinois, the Court had reached the puzzling conclusion that a passenger in an automobile has no standing to challenge the search of the vehicle itself because the passenger has no legitimate expectation of privacy in the vehicle. ${ }^{108}$ This holding alone is probably inconsistent with everyday notions of privacy. Houghton, however, went further. Unlike Rakas, Houghton did not involve a search of compartments in the vehicle, but extended the permissive warrantless search to the passenger's effects themselves. ${ }^{109}$ The majority again relied on the diminished expectation of privacy theory; this time for items placed in vehicles, and also opined that the passenger might be in cahoots with the driver. ${ }^{110}$ Houghton again involved drugs. ${ }^{111}$

\section{Search Incident to Vehicular Arrest}

It comes as no surprise that the Court has taken a very expansive view of a search incident to a vehicular arrest. In Chimel v. California, the Court had limited the scope of a search incident to arrest to the function it was designed to serve-preventing the use of weapons and the destruction of evidence by

\footnotetext{
104. Id. at 568 .

105. Id. at 598 (Stevens, J., dissenting).

106. 526 U.S. 295 (1999).

107. Id. at 298 .

108. 439 U.S. 128, 148 (1978). In Rakas, a sawed-off rifle was found under the front passenger seat and a box of rifle shells was found in the locked glove compartment. Id. at 130.

109. Houghton, 526 U.S. at 302-03.

110. Id. at 303-05.

111. Id. at 298
} 
the arrestee. ${ }^{112}$ Such a search was thus limited to the person of the suspect and the immediate area into which he might reach to seize a weapon or destroy evidence. ${ }^{13}$ Just what that area covered in the case of an arrest in an automobile was, of course, unclear. Predictably, in Belton v. New York the Supreme Court took the broadest possible interpretation of the Chimel rule as it applied to vehicles, authorizing an incident-to-arrest search of the entire interior of the vehicle (excluding the trunk), including any containers found inside. ${ }^{114}$ This rule applied even though the occupants had been removed from the vehicle and were no longer a realistic threat to reach anything therein. ${ }^{115}$ Such a result, rejecting Chimel's functional analysis, was based on the rationalization of a need for a clear, bright-line rule to guide law enforcement. ${ }^{116}$ The real reason was the War on Drugs.

Just recently, in Thornton v. United States, the Court extended the Belton rule to the situation where the first contact with the suspect occurred after the suspect was outside the vehicle. ${ }^{117}$ Although the officer had probable cause to believe that Thornton had committed a traffic violation, the officer approached him on foot after he had parked and exited the vehicle. ${ }^{118}$ Rejecting the approach applied by some jurisdictions that the Belton rule applied only where police contact was initiated while the arrestee was an occupant of the vehicle, Chief Justice Rehnquist's majority opinion again concluded that a bright-line rule was needed, and that Belton applied as long as the arrestee was a recent occupant. ${ }^{119}$ He concluded that although the arrestee's status as a "recent occupant" might turn on his temporal or spatial relationship to the car at the time of arrest, it did not depend on whether he was inside or outside the car at the time of first contact. ${ }^{120}$ In other words, the Belton search-incident-to-avehicular-arrest rule would apply as long as the arrestee had some relationship to a vehicle at the time of arrest. A gun rather than drugs was found in Thornton's car, but the justification for the search was an arrest for possession of marijuana, ${ }^{121}$ and the officer was no doubt looking for more drugs in the car.

112. 395 U.S. 752,768 (1969).

113. Id.

114. 453 U.S. 454, 460 (1981).

115. Id. In Belton, the four occupants had been ordered out of the car and placed under arrest before the vehicle was actually searched. $I d$. at 456 .

116. Id. at 458 .

117. 124 S. Ct. 2127,2129 (2004).

118. Id. at 2129 .

119. Id. at 2131-32.

120. Id. at 2131-32.

121. Id. at 2129. 
The message of cases like California v. Acevedo, Belton, and Thornton is that if a container comes in contact with a vehicle or a person who is arrested recently has exited a vehicle, then the container or vehicle can be searched without a warrant. ${ }^{122}$ The automobile has become a constitutional lightning rod in the drug war.

\section{Inventory Searches}

There is one situation where an automobile can be searched without probable cause or even suspicion. When the police take custody of a vehicle-impound it-because the driver has been arrested ${ }^{123}$ or the vehicle has been disabled or illegally left on the street, it and all containers found inside can be "inventoried." 124 In a series of cases culminating in Colorado $v$. Bertine, ${ }^{125}$ the Supreme Court concluded that this practice was justified to protect the owner's property and to protect the police from harm and false property claims. ${ }^{126}$

Such a rationale would be more plausible in the case of valuable or dangerous items visible in the vehicle. It becomes more questionable when closed containers (e.g., backpacks, suitcases, purses) or locked trunks are opened. Where the owner is present, a call to a relative or friend to pick up the vehicle would answer all of the court's concerns, and certainly a locked car in the police impound area would be sufficient to protect the owner's property. The concerns about successful false property claims or a bomb in the car to justify a full inventory of a vehicle and all its contents are hardly persuasive. Since the primary justification for an inventory, protection of the owner's property, adequately can be met by other alternatives, ${ }^{127}$ the majority of the

122. See supra notes 103-05, 114-21 and accompanying text.

123. Colorado v. Bertine, 479 U.S. 367 (1987). Generally the arrest of the driver would justify a search of the vehicle incident to arrest. However, such a search legally could not extend beyond the interior of the automobile to, for example, the trunk.

124. South Dakota v. Opperman, 428 U.S. 364, 369 (1976).

125. Bertine, 479 U.S. at 372; see also Illinois v. Lafayette, 462 U.S. 640, 646-47 (1983); Opperman, 428 U.S. at 369.

126. Bertine, 479 U.S. at 373.

127. Inventories themselves are commonly of such low administrative quality that they may not be adequately protective of the owner's property or the police from false claims, thus further undermining the Court's justification for allowing them with almost no Fourth A mendm ent concern. For example, in Bertine, the police's inventory (described by the trial court as "slipshod" — a description dis senting Justice Mars hall called "the height of understatement") failed to list the following contents of the vehicle: $\$ 150$ cash in the defendant's wallet, $\$ 210$ cash in an envelope marked "rent," the defendant's credit cards, a converter, a hydraulic jack and a set of tire chains. Id. at 383 (Marshall, J., dissenting). An additional $\$ 700$ cash that 
Justices in these cases can be charged with disingenuity. The inventory cases all involved drugs.

\section{Vehicular Stops, Custody, and Pretextual Encounters}

Although the Supreme Court held in Delaware v. Prouse ${ }^{128}$ that for other than administrative checkpoints ${ }^{129}$ reasonable suspicion is required to stop a vehicle, ${ }^{130}$ this is not much of a standard given the multitude of traffic violations and the leniency of suspicion in regard thereto. This takes on more ominous significance when viewed in conjunction with the Court's earlier decisions in the companion cases of United States v. Robinson ${ }^{131}$ and Gustafson v. Florida, ${ }^{132}$ and the much more recent case of Atwater v. City of Lago Vista. ${ }^{133}$

In both Gustafson and Robinson, Justice Rehnquist's majority opinions concluded that when someone arrested for a traffic violation is taken into custody - what the majority called "a full custody arrest"- a full search of the person is justified based on the need to disarm the suspect in order to take him into custody. ${ }^{134}$ Regardless of the unlikelihood of the existence of weapons in a traffic stop or the absence of Terry-type suspicion of their presence, the majority concluded that the extended exposure of the officer during a custodial arrest justified the full search. ${ }^{135}$ This extended exposure rationale makes sense in the context of a legitimate custodial arrest. It becomes more suspect, however, in the case of the typical traffic arrest where most reasonable officers would not consider the custody option. ${ }^{136}$ Robinson was arrested for operating

\footnotetext{
was found with the contraband that formed the basis of the charges was not originally listed by the officer perform ing the inventory. Id.

128. 440 U.S. 648 (1979).

129. See Mich. Dep't of State Police v. Sitz, 496 U.S. 444, 455 (1990).

130. Prouse, 440 U.S. at 663.

131. 414 U.S. 218 (1973).

132. 414 U.S. 260 (1973).

133. 532 U.S. 318 (2001).

134. Gustafson, 414 U.S. at 265-66; Robinson, 414 U.S. at 234-35.

135. Gustafson, 414 U.S. at 265-66; Robinson, 414 U.S. at 234-35.

136. State statutory provisions often govern the discretion of a police officer regarding an arrest for a traffic violation. Some states have statutorily or judicially (via constitutional interpretation) limited an officer's ability to arrest for traffic infractions. These states include California, CAL. PENAL CODE $\S 853.6$ (West 1985), North Dakota, N.D. CENT. CODE § 39-07-07 (1997), Oklahoma, OKLA. STAT. ANN. tit. 22, $\S 1115.1$ (West 2002), Oregon, OR. REV. STAT. ANN. § 810.410(3)(a) (1989), Virginia, VA. Code ANN. $\S 19.2$-74 (2004), W ashington, W ASH. REV. CODE ANN. § 10.31.100 (West 2002), and West Virginia, W. VA. CODE ANN. § 17C-19-3 (LexisNexis 2004). Other states vest near absolute discretion with a police officer regarding arrest for traffic violations. These states include Georgia, GA. CODE ANN. § 17-4-20 (West
} 
a motor vehicle after revocation of his operator's permit, and District of Columbia police training regulations required the officer to affect a custodial arrest in this situation, ${ }^{137}$ but Gustafson, in the companion case, was arrested for failure to have his operator's permit in his possession, ${ }^{138}$ hardly your normal occasion for taking someone into custody. This is the troubling part of these cases, for as pointed out by Justice Marshall's dissenting opinions and Justice Stewart's concurring opinion in Gustafson, the holding permits the pretextual custodial arrest for a traffic violation, one which normally would occasion a citation only, in order to make a full search of the person. ${ }^{139}$ Also, it must be remembered that when the driver is arrested and taken in to custody, a full search of the interior of the vehicle and all containers found inside can be made incident to the arrest. ${ }^{140}$

Recently, in Atwater v. City of Lago Vista,${ }^{141}$ the Supreme Court had an opportunity to put a halt to this discretionary and potentially pretextual practice. Atwater was stopped and ultimately arrested for failure to have fastened her seatbelt as well as those of her children. ${ }^{142}$ She was taken into custody, subjected to booking procedures including having her "mug shot" taken, and detained for about an hour before being released on bond. ${ }^{143}$ The Court, in an opinion by Justice Souter, rejected both her breach-of-the-peace for custodial arrest argument as not dictated by the common law and inconsistent with longstanding state and federal practice, and her argument that a custodial arrest should be forbidden when a conviction for the offense carried no jail time or there was no other compelling reason for detention. ${ }^{144}$ As to the latter, Justice Souter rejected the jailable versus fine-only distinction as impracticable for the police to implement given complex penalty schemes and the variety of factual conditions which might lead to differences in sentencing. ${ }^{145}$

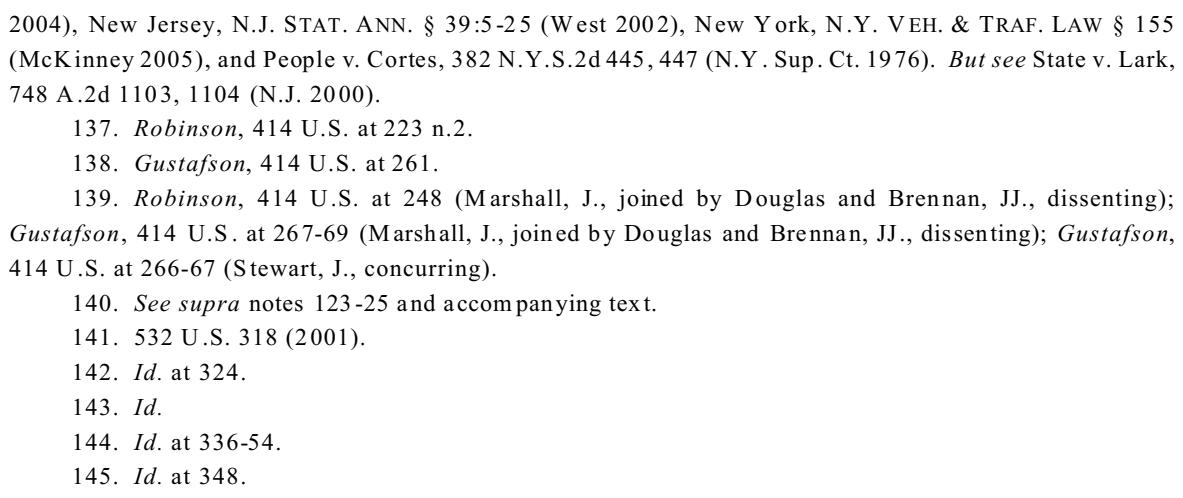


Justice O'Connor, for the four dissenters, responded:

Under today's holding, when a police officer has probable cause to believe that a fineonly misdemeanor offense has occurred, that officer may stop the suspect, issue a citation, and let the person continue on her way. Or, if a traffic violation, the officer may stop the car, arrest the driver, search the driver, search the entire passenger compartment of the car including any purse or package inside, and impound the car and inventory all of its contents. Although the Fourth Amendment expressly requires that the latter course be a reasonable and proportional response to the circumstances of the offense, the majority gives officers unfettered discretion to choose that course without articulating a single reason why such action is appropriate. ${ }^{146}$

She goes on to point out the "grave potential for abuse," either in the form of racial profiling or otherwise using a traffic stop as a pretext for further investigation, ${ }^{147}$ a practice sanctioned by Whren v. United States. ${ }^{148}$

In Whren, the Court had earlier held that subjective motivations for a traffic stop are irrelevant as long as probable cause exists for the detention. ${ }^{149}$ The petitioners had argued that compliance with the multitude of traffic laws is virtually impossible and that police will invariably be able to stop a motorist for a technical violation as a springboard for further investigation. ${ }^{150}$ Nonetheless, the Court was unbowed. The Robinson-Gustafson-AtwaterWhren line of cases literally now permits the police to use the traffic stop, and the invasion that it entails, as a justification for a drug investigation. ${ }^{151}$

\section{E. Drug Testing}

The Court's drug testing cases, beginning with the relatively innocuous decisions in National Treasury Employees Union v. Von Raab ${ }^{152}$ and Skinner v. Railway Labor Executives' Ass' $n,{ }^{153}$ are a paradigm of the War on Drugs. Although drug testing based on individual reasonable suspicion had been approved by lower courts, in these two cases the United States Supreme Court approved suspicionless drug testing of employees who apply for positions in drug interdiction or ones that require the carrying of a firearm (Von Raab), and

146. Id. at 372 (O'Connor, J., dissenting) (citations omitted).

147. Id.

148. 517 U.S. 806 (1996).

149. Id. at 813 .

150. Id. at 810 .

151. See United States v. Mesa, 62 F.3d 159, 162 (6th Cir. 1995); United States v. Roberson, 6 F.3d

1088, 1092 (5th Cir. 1993); State v. Dom inguez-Martinez, 895 P.2d 306, 309 (Or. 1995)

152. 489 U.S. 656 (1989).

153. 489 U.S. 602 (1989). 
the testing of railroad employees following major train accidents or the violation of certain safety rules (Skinner). ${ }^{154}$ In both cases, a reasonableness balancing process was employed, the Court finding that in each case the government interests in drug interdiction and safety outweighed the "diminished expectation of privacy" of those who apply for or hold these positions. ${ }^{155}$

These somewhat narrow holdings were largely overshadowed, however, by the Court's later school drug testing cases, Vernonia School District $47 \mathrm{~J} v$. Acton ${ }^{156}$ and Board of Education of Independent School District No. 92 of Pottawatomie County v. Earls. ${ }^{157}$ In Acton, Justice Scalia's majority opinion again applied a somewhat case-specific balancing approach. ${ }^{158}$ Although recognizing that "students within the school environment have a lesser expectation of privacy than members of the population generally," he emphasized that student athletes have even lesser privacy expectations by subjecting themselves to a degree of regulation beyond that imposed on other students. ${ }^{159} \mathrm{He}$ also relied on the findings below that there was a crisis of student unrest fueled by alcohol and drug abuse for which athletes' drug use served as a role model. ${ }^{160}$ Finally, his opinion pointed to the particular danger to athletes of drug usage. ${ }^{161}$ After relying on these specific factors, Justice Scalia "caution[ed] against the assumption that suspicionless drug testing will readily pass constitutional muster in other contexts." 162

This caution was short-lived. Seven years later in the Earls decision, a majority of the Court upheld a suspicionless, random, drug-testing program applicable to middle and high school students who participated in any extracurricular activity. Justice Thomas's majority opinion de-emphasized the focus in Acton on student-athletes, stating that factor "was not essential to our decision," 163 and concluded that all students who participate in any extracurricular activity "voluntarily subject themselves"164 to additional

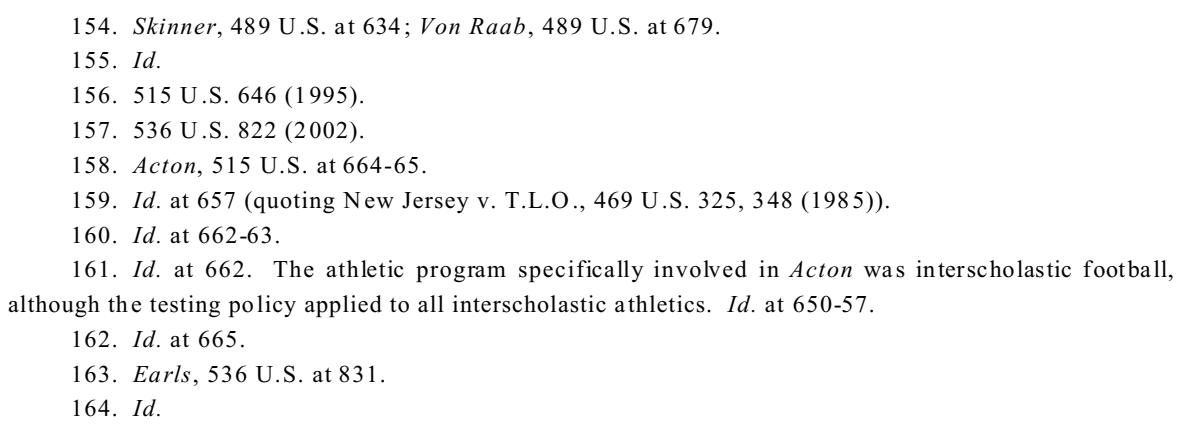


regulations resulting in reduced expectations of privacy. Thomas also substantially expanded the governmental concern regarding the particular drug problem at the school in Acton relied on by Justice Scalia, arguing that it suffices that "the nationwide drug epidemic makes the war against drugs a pressing concern in every school." 165 Justice Thomas also found that the method of collecting the samples and the limited uses to which they were put were "minimally intrusive," and thus "the invasion of the student's privacy is not significant." 166 The majority opinion concluded by finding that "testing students who participate in extracurricular activities is a reasonably effective means of addressing the School District's legitimate concerns in preventing, deterring, and detecting drug use." 167

The Supreme Court has thus moved from the rather narrow constitutional authorization of suspicionless drug testing in Skinner and Von Raab through the expansion in Acton to virtually complete permissiveness in Earls, at least in the public school context. Again, in the name of the War on Drugs, which Justice Thomas's majority opinion in Earls specifically mentions, the Court has permitted governmental intrusion into privacy without any individualized justification whatsoever. Even viewed in isolation, this cannot be described fairly as minor (at least for the students and parents subjected to these policies), but when added to the other previously discussed, Court-sanctioned, police and government practices limiting privacy rights, a substantial intrusion of civil liberties has taken place well before 9/11.

\section{F. A Brief Hesitation}

An indication that the court itself may have recognized this trend and decided to gear down slightly came in the 2000-01 decisions of City of Indianapolis v. Edmond, ${ }^{168}$ Kyllo v. United States, ${ }^{169}$ and Ferguson v. City of Charleston, ${ }^{170}$ each concerning different detection practices. Ferguson itself was a drug-testing case involving a city task force practice of identifying and testing pregnant patients suspected of drug use. The results were turned over to law enforcement for prosecution for drug abuse and/or child neglect. ${ }^{171}$

165. Id. at 834 . Justice Thomas did suggest that there was evidence of drug use at the schools in question. Id. at 834-35. The decision, however, does not appear to rest on this factor.

166. Id. at 834

167. Id. at 837 .

168. 531 U.S. $32(2000)$.

169. 533 U.S. 27 (2001).

170. 532 U.S. 67 (2001).

171. Id. at $70-73$. 
Although Justice Stevens's majority opinion relied on this as the "critical difference" 172 from the Court's other drug-testing cases to invalidate the practice, the point is a fine one and the decision may have signaled a reluctance to go any further and permit drug testing wholesale.

Kyllo v. United States involved the use of a thermal imaging device to measure the heat emanating from a home created by high intensity lamps used to facilitate marijuana growth. ${ }^{173}$ Probable cause for the search warrant was based, in part, on this information. ${ }^{174}$ Justice Scalia's majority opinion ${ }^{175}$ relied on the historical sanctity of the home, "with roots deep in the common law,"176 to declare this "intrusion into a constitutionally protected area" 177 to be an illegal search. Justice Scalia rejected the Government's contentions that thermal imaging (1) measured only off-the-wall heat "radiating from the external surface of the house" rather than "through-the-wall surveillance," 178 and (2) did not "detect private activities occurring in private areas." ${ }^{179}$ Kyllo upholds the home as the centerpiece of the Fourth Amendment, and at the very least indicates that the War on Drugs will not generally be fought inside a dwelling without a properly obtained search warrant.

Finally, two cases involving drug-sniffing dogs are instructive: one because it seems to side with Ferguson and Kyllo in slowing the assault on privacy, and the other more recent one because it renews that trend. City of Indianapolis v. Edmond, mentioned above, invalidated city-operated vehicle checkpoints using dogs to interdict unlawful drugs. The majority, per Justice O'Connor, distinguished the Court's other cases where checkpoints had been upheld ${ }^{180}$ because those cases did not involve checkpoint programs "whose primary purpose was to detect evidence of ordinary criminal wrongdoing." "181 In other words, the other checkpoints had been approved because of special

172. Id. at 79

173. Kyllo, 533 U.S. at 29

174. Id. at 30 .

175. Justice Scalia also recently found himself in the uncustomary position of writing the majority opinion in favor of the criminal defendant in Crawford v. Washington, 541 U.S. 36 (2004) (declaring the use of testimonial hearsay to be a violation of the Sixth Amendment right to confrontation), and Blakely $v$. Washington, 542 U.S. 296 (2004) (declaring Washington's sentencing scheme to be a violation of the Six th Am endment right to trial by jury).

176. Kyllo, 533 U.S. at 34.

177. Id. (quoting Silverman v. United States, 365 U.S. 505, 512 (1961)).

178. Id. at 35 .

179. Id. at 37

180. Edmond, 531 U.S. at 37-40.

181. Id. at 38 . 
needs, such as detecting illegal aliens and deterring drunk driving, instead of detecting ordinary criminal conduct.

Unfortunately, Illinois v. Caballes, ${ }^{182}$ decided during the 2004-05 Term, indicates that this brief foray into the protection of personal privacy may be short-lived. Caballes was different than Edmond in that a lawful traffic stop had already occurred (driving $71 \mathrm{~m}$. .p.h. on an interstate highway with a speed limit of 65). ${ }^{183}$ The dog was brought to the scene during this lawful detention, ${ }^{184}$ alerted positive, and marijuana was found in a search of the car's trunk. Justice Stevens's majority opinion not only followed established precedent that a dog sniff was not a search for Fourth Amendment purposes, but also rejected the Illinois Supreme Court's conclusion that the use of the dog converted a lawful traffic stop into a different drug investigation not supported by reasonable suspicion. Justice Stevens stated, "In our view, conducting a dog sniff would not change the character of a traffic stop that is lawful at its inception and otherwise executed in a reasonable manner, unless the dog sniff itself infringed respondent's constitutionally protected interest in privacy. Our cases hold that it did not." 185 What this holding means, of course, is that every citizen facing a routine traffic stop, pretextual or otherwise, is subject to a drug investigation. Law enforcement officers, interested in drug detection, now are not limited to questioning and their own senses when they conduct a traffic stop. A canine unit can be used if readily available. Unless this can simply be written off as another example of the notion that if you are not carrying drugs, you have nothing to fear, ${ }^{186}$ the Court again seems to be back on the path of assaulting privacy and civil liberties to solve drug crimes.

This was confirmed by the rather ominous decision last Term in Hudson v. Michigan ${ }^{187}$ another drug (and gun) case. Although the issue addressed in Hudson was limited to the not insignificant one of whether violation of the "knock-and-announce" rule should result in the exclusion of evidence found in the search, Justice Scalia's opinion for the Court carried much broader

182. 125 S. Ct. $834(2005)$

183. Id. at 841 n.4 (S outer, J., dissenting).

184. Justice Stevens's majority opinion indicated that the outcome might well be otherwise if the stop itself became illegal because unlaw fully extended. Id. at 837 (majority opinion).

185. Id.

186. Justice O'Connor virtually said as much in her majority opinion in Florida v. Bostick, 501 U.S. 429 (1991). In response to the respondent's argument that no "reasonable person" would consent to the search of luggage that he or she knows contains drugs, Justice O'Connor said, "This argum ent cannot prevail because the 'reasonable person' test presupposes an innocent person." Id. at 437-38.

187. 126 S. Ct. 2159 (2006). 
overtones. His majority opinion began by applying the now familiar analysis of balancing the advantages of applying the exclusionary rule to a particular constitutional violation against its social costs. Justice Scalia first concluded that violation of the "knock-and-announce" rule was not even a but-for cause of obtaining the evidence. "Whether that preliminary misstep had occurred or not, the police would have executed the warrant they had obtained, and would have discovered the gun and drugs inside the house." 188 He next reached the questionable conclusion that the interests served by the rule-preventing violence and the destruction of property, and protecting the occupant's dignity - would not be served directly by the exclusion of the evidence obtained. When turning to the "social costs" side of the ledger, in addition to the loss of evidence and criminal convictions, Justice Scalia suggested a flood of litigation over alleged failures to observe the rule or the justification for an unannounced entry, together with discouraging police from making timely entry after knocking and announcing. Although the analysis at this point was enough to sustain avoidance of the exclusionary rule, Justice Scalia returned to the advantages of the exclusion side of the balance to consider deterrence of the police. Here is where the opinion gets ominous for the future of the exclusionary rule generally because Scalia's remarks apply well beyond violation of the "knock-and-announce" rule. He hints that the exclusion of evidence may no longer be necessary because things have changed since the days of Mapp v. Ohio, suggesting that civil suits and accompanying attorney's fees, along with increasing professionalism and a new emphasis on internal police discipline, may be adequate remedies to deter police misbehavior. ${ }^{189}$

Justice Kennedy's concurring opinion provided the necessary fifth vote for Justice Scalia's opinion for the Court. ${ }^{190}$ He stated, "[T]he continued operation of the exclusionary rule, as settled and defined by our precedents, is not in doubt. Today's decision determines only that in the specific context of the knock-and-announce requirement, a violation is not sufficiently related to the later discovery of evidence to justify suppression."191 Nevertheless, he joined all but the last part of Justice Scalia's opinion (which described the application of three earlier cases to his analysis, and was not directly related to his deterrence discussion). Although the dissent focused on the knock-andannounce analysis and not the portentous consequences of the majority

188. Id. at 2164 .

189. Id. at $2176-68$

190. Id. at 2170-71 (Kennedy, J., concurring). Justice Breyer, joined by Justices Stevens, Souter, and Ginsburg, dissented. Id. at 2171-86 (B reyer, J., dissenting).

191. Id. at 2170 (Kennedy, J., concurring). 
opinion, the new Roberts Court may be beginning to flex its muscles. The War on Drugs (and civil liberties) may be fought in this venue with a vengeance.

\section{THE WAR ON TERRORISM}

My goal here in describing government action in the name of security that substantially impacts civil liberties, both before and primarily after $9 / 11$, is not to cover these laws in detail. Others have done that. My interest instead is to briefly describe these national security measures to portray how, on the heels of and in conjunction with the War on Drugs, they have further undermined liberty and privacy interests. It is the overall impact, the cumulative effect, of these wars (on drugs and terrorism) over the past thirty years with which we should be concerned.

\section{A. Pre-9/11: The Antiterrorism and Effective Death Penalty Act of 1996}

In the wake of the bombing of the Murrah Federal Building in Oklahoma City in 1995, Congress passed the Antiterrorism and Effective Death Penalty Act, which encompassed two innovative federal crimes. ${ }^{192}$ According to 18 U.S.C. $\S 2339$ A, it is a federal crime to provide material support or resources for acts of terrorism, ${ }^{193}$ and 18 U.S.C. $\$ 2339$ B criminalizes providing material

192. Antiterrorism and Effective Death Penalty Act of 1996, Pub. L. No. 104-132, $\S \S 221,303,323$, 110 Stat. $1214,1241,1250,1255$.

193. 18 U.S.C.A. $§ 2339$ A (West 2000 \& Supp. 2005).

Providing material support to terrorists

(a) Offense. Whoever provides material support or resources or conceals or disguises the nature, location, source, or ownership of material support or resources, knowing or intending that they are to be used in preparation for, or in carrying out, a violation of section $32,37,81,175,229,351,831$, $842(\mathrm{~m})$ or (n), 844(f) or (i), 930(c), 956,1114, 1116, 1203, 1361, 1362, 1363, 1366, 1751, 1992, $1993,2155,2156,2280,2281,2332,2332 \mathrm{a}, 2332 \mathrm{~b}, 2332 \mathrm{f}$, or $2340 \mathrm{~A}$ of this title, section 236 of the Atom ic Energy Act of 1954 (42 U.S.C. 2284), section 46502 or 60123(b) of title 49, or any offense listed in section 2332b(g)(5)(B) (except for sections 2339A and 2339B) or in preparation for, or in carrying out, the concealment of an escape from the commission of any such violation, or attem pts or conspires to do such an act, shall be fined under this title, imprisoned not more than 15 years, or both, and, if the death of any person results, shall be imprisoned for any term of years or for life. . . (b) Definitions. As used in this section-

(1) the term "material support or resources" means any property, tangible or intangible, or service, including currency or monetary instruments or financial securities, financial services, lodging, training, expert advice or assistance, safehouses, false documentation or identification, communications equipment, facilities, weapons, lethal substances, explosives, personnel ( 1 or more individuals who may be or include oneself), and transportation, except medicine or religious materials; 
support or resources to designated terrorist organizations. ${ }^{194}$ These provisions are unique and stretch criminal liability in several important respects.

First, although sections 2339A and B are complicity/conspiracy-like offenses in that they punish affiliation and aid, ${ }^{195}$ they require only the mens rea of knowledge ${ }^{196}$ as opposed to the purpose (or specific intent) normally necessary to make one responsible as a conspirator or accomplice. ${ }^{197}$ Aiding with knowledge has generally not been sufficient to establish the latter kind of criminal liability. ${ }^{198}$ When this is coupled with the fact that $\S 2339 \mathrm{~A}$ and $\S 2339 \mathrm{~B}$ are themselves substantive offenses, not requiring the commission of

(2) the term "training" means instruction or teaching designed to impart a specific skill, as opposed to general knowledge; and

(3) the term "expert advice or assistance" means advice or assistance derived from scientific, technical or other specialized knowledge.

Id.

194. 18 U.S.C.A. § 2339B (West 2000 \& Supp. 2005).

Providing material support or resources to designated foreign terrorist organizations

(a) Prohibited activities.-

(1) Unlawful conduct. Whoever knowingly provides material support or resources to a foreign terrorist organization, or attempts or conspires to do so, shall be fined under this title or imprisoned not more than 15 years, or both, and, if the death of any person results, shall be imprisoned for any term of years or for life....

(g) Definitions. As used in this section...

(4) the term "material support or resources" has the same meaning given that term in section 2339A (including the definitions of "training" and "expert advice or assistance" in that section); . .

(6) the term "terrorist organization" means an organization designated as a terrorist organization under section 219 of the Immigration and Nationality Act.

195. Sections 2339 A and B create substantive liability unlike the secondary liability created by conspiracy and complicity law for the substantive offenses committed by the conspiracy or principal actors with whom one is an accomplice. The practical result is that a person can be charged with both a violation of these aiding-terrorism offenses and possibly also substantive offenses committed by those aided.

196. Section 2339B requires the mental state of acting "knowingly," § 2339B(a)(1), whereas $\$ 2339 \mathrm{~A}$ covers the provision of material support or resources "knowing or intending" that they be used in an act of terrorism, §2339A(a) (emphasis added).

197. Model Penal CODE $\S 2.02$ (1962). The American Law Institute's Model Penal Code (MPC) is fairly representative of the difference. Under the MPC, a person acts "purposely" when it is "his conscious object to engage in conduct... or cause a result," §2.02(2)(a) (emphasis added), whereas acting "knowingly" requires awareness of the nature of the conduct or aw areness that it is "practically certain that his conduct will cause ... [the] result," $§ 2.02(2)(b)$ (emphasis added). Under the MPC, knowledge is also established "if a person is aware of a high probability of its existence," $\S 2.02(7)$.

198. See United States v. Falcone, 311 U.S. 205 (1940); United States v. Peoni, 100 F.2d 401 (2d Cir. 1938); People v. Beeman, 674 P.2d 1318 (Cal. 1984); People v. Lauria, 59 Cal. Rptr. 628 (Cal. Ct. App. 1967); M Odel PenAl CODE $§ 5.03(1)$ (1962); see also Baruch Weiss, What Were They Thinking?: The Mental States of the Aider and Abettor and the Causer Under Federal Law, 70 FORDHAM L. REV. 1341 (2002); Paul Marcus, Criminal Conspiracy: The State of Mind Crime-Intent, Proving Intent, and AntiFederal Intent, 1976 U. ILL. L.F. 627. But see Backun v. United States, 112 F.2d 635 (4th Cir. 1940). 
any independent criminal act as in the case of complicity, ${ }^{199}$ the reach of the federal criminal arm is substantial. For example, anyone who engages in a financial transaction with or provides supplies to a person or group planning an act covered by $\S 2339 \mathrm{~A}$ is potentially subject to arrest and prosecution. Dealing with or providing materials to a designated "terrorist organization" under $\S 2339 \mathrm{~B}$ is likewise vulnerable to prosecution. Obviously, there are cases deserving of prosecution here, ${ }^{200}$ but there is also cause for concern for the same reasons that the law of conspiracy and complicity has generally rejected broad aiding-with-knowledge responsibility. ${ }^{201}$

Section 2339B, on its face, suffers from due process infirmities. As mentioned above, this section makes it a federal crime to provide material support or resources to a foreign terrorist organization (FTO). This statute does not define such an entity, but instead states that a terrorist organization is "an organization designated as a terrorist organization under section 219 of the Immigration and Nationality Act." ${ }^{202}$ This latter provision gives the Secretary of State, in consultation with the Secretary of the Treasury and Attorney General, the authority to designate a group as a foreign terrorist organization if the group is foreign, engages or has the intent to engage in terrorist activity, and threatens the national security of the United States. ${ }^{203}$ The statute does not require that an organization be given notice of the designation process, and the group is not provided any opportunity to present information challenging the designation before it is made. ${ }^{204}$ Although the United States Court of Appeals for the District of Columbia is given the power to review the designation, ${ }^{205}$ review is limited to the administrative record, including classified material. ${ }^{206}$ The designated organization is not permitted to present any information to the court. ${ }^{207}$

The D.C. Circuit held in People's Mojahedin Organization of Iran (PMOI) v. Department of State ${ }^{208}$ and National Council of Resistence of Iran

199. This would include a completed attempt to commit a substantive offense.

200. See, e.g., United States v. Rahmani, 209 F. Supp. 2d 1045 (C.D. Cal. 2002).

201. Reasons include the uncertainty of the culpability of knowledge alone in this context and reluctance to punish otherwise legitimate commercial activity. See WAYNE R. LAFAVE, CRIMINAL LAW $\S 12.2(\mathrm{c})(3)$, at $631-33, \S 13.2(\mathrm{~d})$, at 678-80 (4th ed. 2003).

202. 18 U.S.C. $\S 2339 B(\mathrm{~g})(6)$ (2000) (referring to 8 U.S.C.A. $§ 1189$ (2000)).

203. 8 U.S.C.A. § 1189 (a)(c) (West 2000 \& Supp. 2005).

204. Id. $\S 1189$ (a)(2)(A).

205. Congress also has the power to reverse the designation. Id. $\S 1189$ (a)(2)(B)(ii) (West 2000 \& Supp. 2005).

206. Id. $\S 1189(6)(2)$.

207. Id. $\S 1189(\mathrm{a})(3)(\mathrm{B})(6)(2)$.

208. 182 F.3d 17 (D.C. Cir. 1999). 
v. Department of State ${ }^{209}$ that the lack of notice and absence of an opportunity to be heard prior to the designation violated due process for organizations who had a presence in the United States. The PMOI holding, however, specifically did not apply to organizations without a U.S. presence, ${ }^{210}$ and, more importantly, these decisions have nothing to say about the ability of a defendant charged with violating $\S 2339 \mathrm{~B}$ to challenge the designation process in the criminal prosecution. Section 2339B does not make it a crime to provide support or resources to a terrorist organization unless the group has been so designated by the Secretary of State. ${ }^{211}$ The two district courts that have decided on the criminal defendant's ability to challenge the designation have reached conflicting results, ${ }^{212}$ leaving defendants charged with violating the already vague perimeters of $\S 2339 \mathrm{~B}$ without any clear recourse to challenge the prosecution on this ground. ${ }^{213}$

Another interesting aspect of both $\S 2339 \mathrm{~A}$ and $\S 2339 \mathrm{~B}$ is how the government has interpreted and used the statutory term "material support or resources," defined in $\S 2339 \mathrm{~A}(\mathrm{~b})$. Although a number of prosecutions using various aspects of this definition have occurred post-9/11, ${ }^{214}$ the government also has taken the expansive position that the term "personnel" in the definition includes providing oneself. In fact, the United States Attorneys' Manual provides:

[t]here are two different ways of providing "personnel" to a designated foreign terrorist organization: 1) by working under the direction or control of the organization; or 2) by

209. 251 F.3d 192 (D.C. Cir. 2001).

210. People's Mojahedin Org. of Iran, 182 F.3d at 22 (holding that "[a] foreign entity without property or presence in this country has no constitutional rights under the due process clause").

211. 18 U.S.C.A. $\$ 2339$ B(a), (g)(6) (West 2000 \& Supp. 2005).

212. In United States v. Rahmani, 209 F. Supp. 2d 1045 (C.D. Cal. 2002), District Judge Takasugi declared that $\S 1189$ 's express refusal to allow a criminal defendant to challenge the designation violated due process, and further held that the absence of notice and hearing requirements in $\S 1189$ could not be read into the statute (as the D.C. Circuit had done), and it was thus unconstitutional on its face. On the other hand, in United States v. Satter, 272 F. Supp. 2d 348, 364 (S.D.N.Y. 2003) (Satter I), Judge Koeltl of the Southern District of New York rejected Judge Takasugi's conclusions. He stressed that $\S 1189$ prohibited review of the designation in a criminal case, argued that the defendants lacked standing because they were trying to raise the constitutional rights of another, and concluded that the element of the offense in a $\S 1189$ prosecution is the designation itself and not the correctness of the designation. Id. at 364-68.

213. See generally Randolph N. Jonakait, A Double Due Process Denial: The Crime of Providing Material Support or Resources to Designated Foreign Terrorist Organizations, 48 N.Y.L. SCH. L. REV. 125 (2004).

214. See Norman Abrams, The Material Support Terrorism Offenses: Perspectives Derived From the (Early) Model Penal Code, 1 J. NAT'L SEC. L. \& POL'Y 5 (2005); Robert M. Chesney, The Sleeper Scenerio: Terrorism-Support Laws and the Demands of Prevention, 42 HARV. J. ON LEGIS. 1 (2005). 
recruiting another to work under its direction or control. The statute encompasses both methods, so long as the requisite direction or control is present. ${ }^{215}$

The government has had success with this theory in two cases since 9/11. ${ }^{216}$ However, in United States $v$. Sattar, which involved the prosecution of attorney Lynne Stewart who represented Sheikh Abdel Rahman, convicted in 1995 of terrorist offenses, District Judge John G. Koeltl of the Southern District of New York rejected the government's theory that Stewart could violate $\S 2339 \mathrm{~B}$ by providing herself as personnel. ${ }^{217}$ Instead of following Lindh (which the judge described as "appl[ying] to a person who provides himself or herself as a soldier in the army of an FTO" ${ }^{218}$ ), Judge Koeltl relied on the pre-9/11 decision in Humanitarian Law Project $v$. Reno, ${ }^{219}$ which held the personnel provision unconstitutionally vague as applied. Particularly troubling to the judge was that it would be difficult for a lawyer representing a leader of a foreign terrorist organization to avoid criminal prosecution even under the government's theory that "personnel" applies only to "employees" or "quasi-employees." 220 But irrespective of Sattar I, and the court's concern for attorney liability under the government's expansive "personnel" theory, at least in some cases, the government can allege that the personnel provided is the defendant himself.

Taken together, these factors (requiring only the mens rea of knowledge, the inability of some organizations and all criminal defendants to challenge the designation of a group as a foreign terrorist organization, and the broad use by the government of the term "personnel" to cover the defendant himself) raise serious potential for infringement of First Amendment expression and associational rights. The Lynne Stewart case, with its surrounding publicity, may prove to be a warning.

215. U.S. DEP'T OF JUSTICE, U.S. ATtORNEYS' M ANUAL § 9-91.100 (2001), available at http://www .usdoj.gov/usao/foia_reading_room/usam/title9/title9.htm.

216. See United States v. Goba, 220 F. Supp. 2d 182, 194 (W.D.N.Y. 2002); United States v. Lindh, 212 F. Supp. 2d 541, 574 (E.D. Va. 2002).

217. Satter I, 272 F. Supp. 2 d at 359.

218. Id.

219. 205 F.3d 1130 (9th Cir. 2000).

220. Satter I, 272 F. Supp. 2 d at 359 . Following this setback, the government changed its theory and issued a superceding indictment, th is time alleging a violation of $\S 2339 \mathrm{~A}$ (instead of $\S 2339 \mathrm{~B}$ ) and alleging that the personnel provided was Sheikh Rahman. This time, the judge upheld the government's claim, United States v. Sattar, 314 F. Supp. 2d 279 (S.D.N. Y. 2004) (Sattar II), and on February 5, 2005, Stewart was found guilty of violating $\S 2339 \mathrm{~A}$ and making a false statement to the government under 18 U.S.C. $\S 1001$ (2000). See Abrams, supra note 214, at 12-16. 


\section{B. The USA PATRIOT Act}

Although the United States has a history of reactionary and repressive behavior in a crisis, ${ }^{221}$ the USA PATRIOT Act ("Unifying and Strengthening America by Providing Appropriate Tools Required to Intercept and Obstruct Terrorism") may prove to be the broadest, wholesale threat to civil liberties in the nation's history. Passed just six weeks after the September 11 attacks, without congressional hearings and floor debate, ${ }^{222}$ the voluminous piece of legislation grants to law enforcement many coveted, but previously rejected, powers. ${ }^{223}$ Since most of its provisions amend and modify existing laws, it is a bill that cannot be read, but only deciphered and analyzed.

Although there are many onerous provisions in the Act, I intend to focus on the ones that most directly threaten privacy and Fourth Amendment protection, which has been my theme all along. These include sections which authorize secret search warrants, provide for roving wiretaps, expand electronic surveillance authority, permit judges to issue nationwide search warrants, and allow the seizure of various business records without probable cause or even proof of reasonable suspicion. Likewise, the definition of "terrorism" in the Act is so broad as to include many domestic crimes, including public protests. My goal here is not to urge repeal because Congress recently re-authorized the Act. ${ }^{224}$ It is rather to emphasize how the pressure to

221. Examples include the Alien and Sedition Act of 1798, President Abraham Lincoln's suspension of the writ of habeas corpus during the Civil War without constitutional authority (later declared unconstitutional by the Suprem e Court in Ex parte Milligan, 71 U.S. 2 (4 Wall.) (1866)), Schenck v. United States, 249 U.S. 47 (1919) and Debs v. United States, 249 U.S. 211 (1919) (both upholding convictions for violating congressional statutes prohibiting criticism of World War I and the draft), the internment of Japanese-Americans during World War II upheld in Korematsu v. United States, 323 U.S. 214 (1944), Dennis v. United States, 341 U.S. 494 (1951) (upholding convictions under the Smith Act of 1940 for conspiracy to overthrow the government by organizing groups to study the works of Marx, Lenin, and Engels), United States v. United States District Court for the Eastern District of Michigan, 407 U.S. 297 (1972) (rejecting secret, warrantless, electronic surveillance for domestic security purposes).

222. See Erwin Chemerinsky, Post 9/11 Civil Rights: Are Americans Sacrificing Freedom for Security?, 81 DENV. U. L. REV. 759, 767 (2004); Gia F enoglio, Jumping the Gun on Terrorism?, 33 NAT'L J. 3450 (2001); Rita Shulman, Note, USA Patriot Act: Granting the U.S. Government Unprecedented Power to Circumvent American Civil Liberties in the Name of National Security, 80 U. DET. MERCY L. REV. 427 , 428 (2003); Jerem y C. Smith, Comment, The USA PATRIOT Act: Violating Reasonable Expectations of Privacy Protected by the Fourth Amendment Without Advancing National Security, 82 N.C. L. REV. 412, 413-16 (2003).

223. Chem erinsky, supra note 222, at 767; Robert M. Duncan, Jr., Surreptitious Search Warrants and the USA PATRIOT Act: "Thinking Outside the Box but With in the Constitution," or a Violation of Fourth Amendment Protections?, 7 N.Y. CITY L. REV. 1, 3 (2004); John Lancaster \& Jonathan Krim, Ashcroft Presents Anti-Terrorism Plan to Congress, WASH. Post, Sept. 20, 2001, at A24.

224. USA PATRIOT Improvement and Reauthorization Act of 2005, Pub. L. No. 109-177, 109 Stat. 
pass, and now retain, this recent piece of legislation has contributed to the tremendous decline in privacy protection and civil liberties in the past thirty years. $^{225}$ Although it is true that the USA PATRIOT Improvement and Reauthorization Act of 2005 does add some privacy protections, which will be noted, most of the troubling provisions remain in tact. The Reauthorization Act makes the original Act permanent except for $\S 206$ (roving surveillance) and $\S 215$ (orders for the production of business records) that are scheduled to expire on December $31,2009 .^{226}$

\section{Sneak-and-Peek Search Warrants}

The Fourth Amendment, through its reasonableness requirement, generally requires notice of authority and purpose to search (the so-called knock-and-announce rule). ${ }^{227}$ Prior to the PATRIOT Act, Rule 41 of the Federal Rules of Civil Procedure, by its notice and inventory provision, likewise required contemporaneous notice of the execution of a search warrant. $^{228}$ There are good reasons for this requirement. Notice allows the subject of the search to point out defects in the warrant or its execution, such as misidentification of the property or person to be searched, and it permits the target to monitor the scope of the search to en sure that it is conducted properly. Most importantly, it deters violence. The notice requirement is thus designed to minimize intrusions into dwellings or business locations, which lie at the heart of Fourth Amendment privacy protection. ${ }^{229}$

For the first time in the nation's history, Section 213 of the PATRIOT Act provides express statutory authorization for the issuance of surreptitious search warrants (so-called sneak-and-peek or covert-entry warrants). ${ }^{230}$ This type of warrant permits officers to enter a home or dwelling without notice, look around, take pictures, examine electronic files, and leave without

\footnotetext{
1389 (2006) [hereinafter Reauthorization Act].

225. On the US A PATRIOT Act, see gen erally STEPHEN J. SCHULHOFER, RETHINKING THE PATR IOT ACT (2005); AmitAi EtZIONi, How PATRIOTIC Is THE PA TRIOT ACT? (2004).

226. Reauthorization Act $\S 102$.

227. See Richards v. W isconsin, 520 U.S. 385 (1997); Wilson v. Arkansas, 514 U.S. 927 (1995).

228. FED. R. CRIM. P. 41(f).

229. See Kyllo v. United States, 533 U.S. 27 (2001).

230. 18 U.S.C. $\$ 3103 \mathrm{a}(\mathrm{b})$ (Supp. I 2001). Shortly after passage of the PATRIOT Act, Congress also amended FED. R. CRIM. P. 41 by adding the following language under Rule 41(a): "Scope and Definitions: (1) Scope. This rule does not modify any statute regulating search or seizure, or the issuance and execution of a search warrant in special circumstances.” FED. R. CRIM. P. 41(a)(1). This means that $\S 213$ prevails over any conflict with Rule 41.
} 
contemporaneous notification to the target that a search has taken place. A sneak-and-peek warrant is usually a precursor to the issuance of a conventional search warrant where property is subsequently seized.

Section 213 of the PATRIOT Act amends 18 U.S.C. $\S 3103$ a by adding subsection (b) permitting "Delay" under certain circumstances. ${ }^{231}$ The statute authorizes delay when "the court finds reasonable cause to believe that providing immediate notification of the execution of the warrant may have an adverse result." 232 The definition of "adverse result," taken from 18 U.S.C. $\S 2705$, which deals with delaying notice for searching e-mail or other stored electronic communications, includes "endangering the life or physical safety of an individual, flight from prosecution, destruction or tampering with evidence, intimidation of potential witnesses, or otherwise seriously jeopardizing an investigation or unduly delaying a trial." 233 Unduly delaying a trial was eliminated as the sole justification for delaying notice by the Reauthorization Act of 2005. ${ }^{234}$ The statute limits delayed notice to situations in which "the warrant prohibits seizure of any tangible property, any wire or electronic communication, .... or, ...., any stored wire or electronic information, except where the court finds reasonable necessity for the seizure." 235 Lastly, the original addition to section 3103 a authorized delay if "the warrant provides for the giving of such notice within a reasonable period of its execution, which period may thereafter be extended by the court for good cause shown." ${ }^{236}$ The 2005 reauthorization contains a presumption for a delay

231. 18 U.S.C. $\S 3103 \mathrm{a}$ (b) (Supp. I 2001).

(b) Delay. With respect to the issuance of any warrant or court order under this section, or any other rule of law, to search for and seize any property or material that constitutes evidence of a criminal offense in violation of the laws of the United States, any notice required, or that may be required, to be given may be delayed if-

(1) the court finds reasonable cause to believe that providing imm ediate notification of the execution of the warrant may have an adverse result (as defined in section 2705) ... ;

(2) the warrant prohibits the seizure of any tangible property, any wire or electronic communication (as defined in section 2510), or, except as expressly provided in chapter 121, any stored wire or electronic information, except where the court finds reasonable necessity for the seizure; and

(3) the warrant provides for the giving of such notice within a reasonable period of its execution, which period may thereafter be extended by the court for good cause shown. Id.

232. Id. $\S 3103 \mathrm{a}(\mathrm{b})(1)$.

233. 18 U.S.C. $\S 2705(\mathrm{a})(2)(2000)$.

234. Reauthorization Act $\S 114$ (b).

235. 18 U.S.C. $\$ 3103 \mathrm{a}(\mathrm{b})(2)$.

236. $I d . \S 3103 \mathrm{a}(\mathrm{b})(3)$. 
up to 30 days and an extension limited to 90 days, but both can be extended if "the facts of the case justify a longer period of delay." 237

To be sure, federal law prior to the PATRIOT Act recognized the legitimacy of surreptitious entry and exit without notice under some circumstances. Title III of the Omnibus Crime Control and Safe Streets Act of 1968 , codified as amended at 18 U.S.C. $\S \S 2510-2521$, provides statutory authorization for electronic surveillance search warrants, and the United States Supreme Court, in Dalia v. United States ${ }^{238}$ recognizing the need for secrecy to install eavesdropping equipment under such a warrant, held that the Fourth Amendment provided no per se prohibition on covert entry. ${ }^{239}$ In addition, the Second and Ninth Circuit Courts of Appeal have upheld surreptitious search warrants in limited circumstances, where there is a showing of reasonable necessity and notice is provided within a reasonable time, generally seven days. ${ }^{240}$ Nonetheless, both courts felt a special need to impose safeguards and closely circumscribe surreptitious entries, ${ }^{241}$ because "surreptitious searches and seizures of intangibles strike at the very heart of the interests protected by the Fourth Amendment," 242 and "to minimize the possibility that the officers will exceed the bounds of propriety without detection." 243

The concern, of course, is that with the new statutory authorization, sneakand-peek warrants will become the rule rather than the exception, as envisioned by the Second and Ninth Circuits. Section 213 is not limited to terrorism, but applies to all criminal investigations, and there is no applicable sunset provision. It does not take a lot of foresight or tax the instincts to realize that law enforcement officers may prefer covert entry to look around, take photographs, and examine computer files and e-mail in order to gain support for a conventional warrant. For example, a 2003 report to Congress

237. Reauthorization Act $\S 114(a)(1)$

238. 441 U.S. 238 (1979).

239. Id. at 248 .

240. See United States v. Pangburn, 983 F.2d 449 (2d Cir. 1993); United States v. Johns, 948 F.2d 599 (9th Cir. 1991) (“Johns II"); United States v. Villegas, 899 F.2d 1324 (2d Cir. 1990); United States v. Johns, 851 F.2d 1131 (9th Cir. 1988) (“Johns I"); United States v. Freitas, 856 F.2d 1425 (9th Cir. 1988) ("Freitas II"); United States v. Freitas, 800 F.2d 1451 (9th Cir. 1986) ("Freitas I"); see also United States v. Simons, 206 F.3d 392 (4th Cir. 2000) (upholding delayed notification under a conventional warrant); Kevin Corr, Sneaky But Lawful: The Use of Sneak and Peek Search Warrants, 43 U. KAN. L. REV. 1103 (1995); Duncan, supra note 223, at 1; James B. Perrine, The USA PATRIOT Act: Big Brother or Business as Usual?, 19 Notre DAME J.L. ETHICS \& PUB. PoL'Y 163, 164-75 (2005); Paul V. Konovalov, Note, On a Quest for Reason: A New Look at Surreptitious Search Warrants, 48 HASTINGS L.J. 435 (1997).

241. Villegas, 899 F.2d at 1336 ; Freitas I, 800 F.2d at 1456.

242. 800 F.2d at 1456 .

243. 899 F.2d at 1336 . 
by the Department of Justice indicated that in the eighteen months after the passage of the PATRIOT Act, the DOJ sought to delay notice to the target 248 times that a surreptitious warrant had been issued, and the Justice Department boasted that it has never been turned down by a court when requesting delayed notification of covert entry. ${ }^{244}$

Because of the vagueness of $\S 213$, the threat to privacy is substantial. First, 18 U.S.C. $\S 3103 a$ (b)(1)'s standard of "reasonable cause" to delay notice is not defined, and the belief in an "adverse result" requirement is much broader than the justifications under current law for dispensing with notice. Under Supreme Court precedent, notification is not necessary when there is a danger of violence, destruction of evidence, or flight. ${ }^{245}$ To this list, the definition of adverse result borrowed from 18 U.S.C. $\S 2705$ adds "intimidation of potential witnesses, or otherwise seriously jeopardizing an investigation," ${ }^{246}$ hardly a narrow or definitive standard. Moreover, the definition is taken from a statute governing delaying notice of searches of electronic communication and applies it to physical entry into the sanctity of the home. At the very least, the statute should be consistent with electronic surveillance law, which before a warrant is issued requires a showing that "other investigative procedures have been tried and failed or why they reasonably appear to be unlikely to succeed if tried or to be too dangerous." ${ }^{247}$ Second, the statute generally prohibits seizures without notice, but contains an exception where a court finds "reasonable necessity for the seizure," ${ }^{248}$ which could amount to nothing more than the plain view seizure of contraband or evidence of crime discovered once covert entry is made.

Although the original delay provision in $\S 3103$ a contained no time period in which notice must be given, only providing for the giving of notice "within a reasonable period of its execution," and permitting an extension "by the court for good cause shown," ${ }^{249}$ the Reauthorization and Improvement Act of 2005 imposes marginally better requirements. There is a presumption that

244. Eric Lichtblau, Justice Dept Lists Use of New Power to Fight Terror, N. Y. TIMES, May 21, 2003, at A1; Duncan, supra note 223, at 4.

245. See Richards v. Wisconsin, 520 U.S. 385 (1997); Wilson v. Arkansas, 514 U.S. 927 (1995); Ker v. California, 374 U.S. 23 (1963).

246. "Unduly delaying a trial" was also included in the original version, but was elim inated as the sole justification for delaying notice by the 2005 Reauthorization Act. See supra note 234 .

247. 18 U.S.C. $\$ 2518(1)(c)$ (2000); see also Foreign Intelligence Surveillance Act of 1978, $\S 104(\mathrm{a})(7)(\mathrm{C}), 50$ U.S.C. $\S 1804(\mathrm{a})(7)(\mathrm{C})(2000)$.

248. 18 U.S.C. $\$ 3103 \mathrm{a}(\mathrm{b})(2)$ (Supp. I 2001).

249. $I d . \S 3103 \mathrm{a}(\mathrm{b})(3)$. 
notice is to be given within thirty days, ${ }^{250}$ and that an extension "should only be granted upon an updated showing of the need for further delay" and "should be limited to periods of ninety days or less." ${ }^{251}$ Both time periods are waived, however, "if the facts of the case justify a longer period of delay." 252 Neither the original Act nor the reauthorization embrace the seven-day requirement endorsed by the Ninth and Second Circuits, ${ }^{253}$ and Senate Judiciary Committee Chairman Arlen Specter. ${ }^{254}$ Although the standard of "an updated showing of need" is better than the former "good cause," it is still so vague as to be virtually meaningless, allowing judges to merely rubber stamp the request. The threat to privacy here is significant because the lengthy notice requirement will encourage law en forcement officials to request surreptitious warrants at the beginning of an investigation - as a crutch or bootstrap - rather than at the end, since notice can be delayed rather indefinitely while the investigation continues. A shorter notice requirement, like the seven days in the bill introduced by Senator Specter, at the very least, would force agents to postpone requests for sneak-and-peek warrants until the end of the investigation or risk premature notification before the investigation is complete. Overall, the breadth and vagueness of the new delayed-notice provision, even as amended, is inconsistent with the protection of privacy embodied in the Fourth Amendment.

\section{Nationwide Service of Search Warrants}

Supplementing, but not limited to, the sneak-and-peek authority is $\S 219$ of the PATRIOT Act, which amends FED. R. CRIM. P. 41(b) to permit the issuance of nationwide search warrants in cases of domestic or international terrorism. ${ }^{255}$ Rule $41(\mathrm{~b})(3)$ now provides:

Authority to Issue a Warrant. At the request of a federal law enforcement officer or an attorney for the government:

(3)

(3) a magistrate judge - in an investigation of domestic terrorism or international terrorism (as defined in 18 U.S.C. $§ 2331$ ) - having authority in any district in which

250. Reauthorization Act $\S 114(\mathrm{a})(1)$

251. Id.

252. Id.

253. United States v. Freitas (Freitas I), 800 F.2d 1451 (9th Cir. 1986); United States v. Johns (Johns II), 948 F.2d 599 (9th C ir. 1991); United States v. Villegas, 899 F.2d 1324 (2d Cir. 1990).

254. Bush Signs Bill Renewing PATRIOT Act With New Provisions to Safeguard Data, 78 CRIM. L. REP. (BNA) 669, 669 (2006).

255. USA PATRIOT Act $\S 219$. 
activities related to the terrorism may have occurred, may issue a warrant for a person or property within or outside the district. ${ }^{256}$

Formerly, the rule authorized the issuance of a warrant for a person or property located only within the district where the warrant was issued. In addition, $\S 802$ of the PATRIOT Act amends 18 U.S.C. $\S 2331$ by adding to its coverage "domestic terrorism" 257 defined to mean activities that:

(A) involve acts dangerous to human life that are a violation of the criminal laws of the United States or of any State;

(B) appear to be intended-

(i) to intimidate or coerce a civilian population;

(ii) to influence the policy of a government by intimidation or coercion; or

(iii) to affect the conduct of a government by mass destruction, assassination, or kidnapping; and

(C) occur primarily within the territorial jurisdiction of the United States. ${ }^{258}$

This provision is broad enough to cover robbery, kidnapping, and even minor acts of civil disobedience, ${ }^{259}$ making nationwide service of search warrants in the case of domestic crime quite probable.

The threat to privacy and civil liberties from the nationwide service of search warrants is three-fold. First, as long as "activities related to the terrorism may have occurred" in the jurisdiction, the rule allows federal agents to shop magistrate judges to get a warrant for searches anywhere in the country. Formerly, they were limited to the magistrates in the jurisdiction where the property was located. Second, the expanded authority effectively prevents magistrates from supervising or screening the execution of warrants cross-country. It will likely prove difficult to particularly describe the places to be searched and the items to be seized in such circumstances, and large geographical distances are likely to embolden federal agents. Third, when the search occurs some distance from the district where the warrant was issued, it will simply be quite difficult for the target to challenge the warrant or its scope either at the time of execution or afterwards prior to the institution of a criminal proceeding. When the statutory authority for surreptitious search warrants is added to the mix, the potential for abuse is tremendous.

\footnotetext{
256. FED. R. CRIM. P. 41(b) (emphasis added).

257. USA PATRIOT Act $\S 802$.

258. 18 U.S.C. $§ 2331$ (5) (Supp. I 2001).

259. See Chemerinsky, supra note 222 , at 767-68.
} 


\section{Enhanced Electronic Surveillance}

Title III of the Omnibus Crime Control and Safe Streets Act of 1968 ("Title III") was a response to the decisions of the United States Supreme Court in Katz v. United States ${ }^{260}$ and Berger v. New York. ${ }^{261}$ In Katz, an electronic surveillance case, the Court shifted the focus of the Fourth Amendment from protecting property to safeguarding privacy expectations, ${ }^{262}$ and in Berger, Justice Clark's majority opinion struck down New York's broad electronic surveillance statute. ${ }^{263}$ Congress responded by passing Title III to control electronic surveillance in the case of domestic law enforcement. ${ }^{264}$ Eighteen years later, Congress amended Title III in the Electronic Communications Privacy Act of 1986 to respond to the increased threat of new technologies to e-mail and internet communication. ${ }^{265}$

Similarly, in response to United States v. United States District Court for the Eastern District of Michigan (Keith, after U.S. District Judge Keith), ${ }^{266}$ which invalidated warrantless electronic surveillance of a radical domestic group but suggested that foreign intelligence gathering might be treated differently for Fourth Amendment purposes ${ }^{267}$ Congress passed the Foreign Intelligence Surveillance Act of 1978 (FISA). ${ }^{268}$ The major difference between the two provisions is that Title III has extensive probable cause, particularity, minimization, and termination requirements regarding the commission of federal domestic crime, ${ }^{269}$ whereas FISA requires only a showing of probable cause that the target is a foreign power or agent of a foreign power ${ }^{270}$ and, originally, certification that "the purpose" of the surveillance was the gathering of foreign intelligence information. ${ }^{271}$ FISA created the Foreign Intelligence Surveillance Court, a court originally composed of seven district judges appointed by the Chief Justice of the United States to review ex parte applications for FISA surveillance warrants. Also

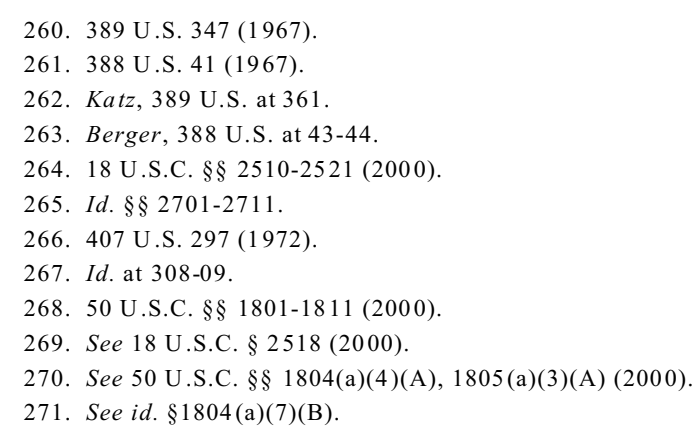


created was a court of review consisting of three other federal judges to review the denial of an application by a FISA judge.

The PATRIOT Act has the capacity to blur the line thus established between electronic surveillance for domestic criminal purposes and the gathering of foreign intelligence information. However, to the extent that the PATRIOT Act expands surveillance power under FISA, it may not necessarily be the big brother that some fear. First, an application for a FISA surveillance order still must establish that the target is a foreign power or agent of a foreign power. ${ }^{272}$ Second, the change made by $\S 218$ diluting certification that "the purpose" of the surveillance is to obtain foreign intelligence information to "a significant purpose" 273 arguably was made to make FISA applicable to terrorism investigations which often involve criminal acts and not just intelligence gathering. ${ }^{274}$

Nonetheless, with the expansion of FISA surveillance to criminal investigations under $\S 218$ and to roving surveillance under $\S 206$, there is serious potential for abuse. Although, generally speaking, FISA cannot be used for criminal investigations involving United States citizens, there are exceptions. First, FISA requires that the target be "a foreign power" or an "agent of a foreign power." 275 A foreign power includes "a faction of a foreign nation or nations" and "a foreign based political organization" that are "not substantially composed of United States persons." 276 This could include individual U.S. citizens. More importantly, "agent of a foreign power" is defined, in part, as "any person who" (1) "knowingly engages in clandestine intelligence gathering activities" on behalf of a foreign power or a foreign power's intelligence service or network in violation of the criminal laws of the United States, (2) knowingly prepares for or engages in sabotage or international terrorism "for or on behalf of a foreign power," (3) knowingly enters the United States or while in the United States uses a false or fraudulent identity for or on behalf of a foreign power, or (4) aids or conspires in any of the above activities. ${ }^{277}$ Although this is certainly broad enough to include U.S. citizens, the 2005 Reauthorization Act may have somewhat inartfully attempted to exclude "United States persons" from the definition. ${ }^{278}$

272. 50 U.S.C. $\S 1804(a)(4)(A)(2000 \&$ Supp. I 2001).

273. See 50 U.S.C. $\$ 1804($ a)(7)(B) (Supp. I 2001 ).

274. See Michael T. McC arthy, Recent Developments, USA PATRIOT Act, 39 HARV. J. ON LEGIS. 435 , 443-44 (2002).

275. 50 U.S.C. $\S 1804(a)(4)(A)(2000 \&$ Supp. I 2001).

276. 50 U.S.C. $\$ 1801$ (a) (2000).

277. Id. $\S 1801$ (b)(2) (emphasis added).

278. Reauthorization Act $\S 105$. 
Nevertheless, any American citizen who communicates with a foreign power or its agents, as defined, would be subject to surveillance under FIS A - (apparently, this is precisely what the Bush administration is engaged in with its secret domestic surveillance program). When this realization is combined with $\S 218$ of the PATRIOT Act's expansion of FISA to cover domestic criminal investigations (the "significant purpose" alteration), there is considerable potential for the more lax standards of FISA surveillance (where the probable cause and particularity requirements of Title III do not have to be met) to be applied to our citizens. Also, FISA is not limited to electronic surveillance, but also applies to physical searches. ${ }^{279}$

Likewise potentially applicable to U.S. citizens in domestic criminal investigations is the expanded roving wiretap authority which $\S 206$ of the PATRIOT Act provides for FISA surveillance. To be sure, so-called roving wiretaps, where the surveillance follows the subject instead of being placed in an identified location, have been authorized under Title III since 1986. The initial amendment to Title III required that the target have a purpose "to th wart interception by chan ging [communications] facilities." 280 In 1998, the stand ard was changed to permit a "roving wiretap" where "there is probable cause to believe that the person's actions could have the effect of thwarting interception from a specified [communications] facility." 281 The breadth of the later amendment, designed to meet modern technology, poses a more serious threat to privacy than the fixed interceptions previously authorized.

It is true, to some extent, that the debate surrounding roving surveillance following $\S 206$ of the PATRIOT Act should really go back twenty years or at least to $1998,{ }^{282}$ except for one significant difference. Section 206 permits roving surveillance under the much looser standards of FISA. ${ }^{283}$ To repeat, roving wiretaps under Title III must satisfy extensive probable cause, particularity, minimization, and termination requirements regarding the commission of criminal acts, ${ }^{284}$ whereas under FISA only probable cause that the target is a foreign power or agent of a foreign power is required, and only

279. 50 U.S.C. $\S \S 1821-1829$ (2000 \& S upp. I 2001).

280. 18 U.S.C. $\S 2518(11)$ (b)(ii) (1998).

281. Intelligence Authorization Act for Fiscal Year 1999, Pub. L. No. 105-272, § 604(a)(1), 112 Stat. 2396, 2413 (1998) (codified at 18 U.S.C. $\$ 2518(11)($ b)(ii) (2000)).

282. See Perrine, supra note 240 , at 175-79.

283. The recent congressional re-authorization of the PATRIOT Act provides for the expiration of $\S 206$ in December 2004. The only other section in the re-authorization to sunset at that time is $\S 215$, the business records provision. Reauthorization Act $\S 102$.

284. Courts have upheld roving surveillance under Title III. See United States v. Bianco, 998 F.2d 1112 (2d Cir. 1993); United States v. Petti, 973 F.2d 1441 (9th Cir. 1992). 
"a significant purpose" of the investigation need be gathering foreign intelligence information. ${ }^{285}$ And, as shown above, U.S. citizens can be subject to the newly authorized roving surveillance under the weaker standards of FISA. Finally, it should be noted that the Foreign Intelligence Surveillance Court's orders are granted and enforced in secret, and thus are not public or known to the target. ${ }^{286}$ Section 208 of the PATRIOT Act expands the number of judges on the secret court from seven to eleven. ${ }^{287}$ Although not a direct threat of additional domestic surveillance, it does increase the number of judges available to issue intercept orders. ${ }^{288}$

This discussion, of course, is overshadowed by the recent disclosure that the administration has been engaged in secret domestic surveillance. In December 2005, the New York Times reported, and the White House later confirmed, that President Bush had authorized the National Security Agency (NSA) to secretly electronically eavesdrop on certain domestic conversations of United States citizens without first obtaining a court order, ${ }^{289}$ contrary to FISA. ${ }^{290}$ In other words, the executive department was evidently violating the law. Although Bush defended the practice as necessary to combat the War on Terror, done with congressional approval, ${ }^{291}$ and authorized by his Article II powers, the argument is specious. Warrantless wiretapping in foreign intelligence cases would seem to be unnecessary; an "un forced error" as one commentator called it. ${ }^{292}$ First, FISA allows emergency surveillance for up to seventy-two hours with out a warrant. ${ }^{293}$ Second, as indicated above, the statute requires only a showing of probable cause that foreign intelligence information

285. The United States Foreign Intelligence Surveillance Court of Review has concluded that $\$ 206$ of the PATRIOT Act, permitting roving wiretaps under FISA, satisfies the Fourth Amendment. In re Sealed Case, 310 F.3d 717 (FISA Ct. Rev. 2002). The precedential value of this holding, however, is unclear since the FISA Court of Review is a court of limited jurisdiction. See Smith, supra note 222, at 412, 423-35 (2003) (arguing that the Foreign Intelligence Surveillance Court of Review's Fourth Amendment analysis was erroneous and has little precedential value).

286. See Rebecca A. Copeland, War on Terrorism or War on Constitutional Rights? Blurring the Lines of Intelligence Gathering in Post-September 11 A merica, 35 TEX. TECH L. REV. 1, 14-16 (2004).

287. USA PATRIOT Act $\S 208$.

288. FIS A still provides that "no judge ... shall hear the same application for electronic surveillance under this chapter which has been denied previously by another judge." 50 U.S.C. § 1803(a) (Supp. I 2001).

289. David E. Sanger, In Address, Bush Says He Ordered Domestic Spying, N.Y. TimeS, Dec. 18, 2005 , at 1 .

290. 50 U.S.C. $\S 1801(2000)$.

291. See S.J. Res. 23, 107th Cong. (2001) (authorizing the use of force after the Sept. 11, 2001, attacks).

292. This Week With George Stephanopolous (ABC television broadcast Dec. 18, 2005) (comment by George Will).

293. 50 U.S.C. $\S 1805(f)(1978)$. 
is being sought, not probable cause that a crime has been committed as in the case of a conventional warrant. ${ }^{294}$ Third, the FIS A court has turned down only a handful among thousands of applications. ${ }^{295}$ To circumvent the legislation set up for the purpose reveals arrogance and a belief in the irrelevance of Congress, and, whether legal or not, exposes the extent to which Americans are subject to electronic surveillance.

If this were not enough, USA Today revealed in May of 2006 that the Government, through a program run by the NSA with the cooperation of AT\&T, Verizon, and BellSouth, has been collecting the phone call records of ten of millions of Americans. ${ }^{296}$ NSA's reported goal is "to create a database of every call ever made" within the nation's borders, and although tracking terrorism is the avowed purpose of the program, with records of billions of domestic calls, the NSA has gained access to the communications habits of millions of Americans, most of whom are not suspected of committing any crime. For customers of the companies involved, the NSA has detailed records of both personal and business calls.

Even though this may not be contrary to the Fourth Amendment, ${ }^{297}$ it appears to violate at least the spirit, if not the letter, of federal law. As mentioned earlier, both Title III of the Omnibus Crime Control and Safe Streets Act of 1968 and the Foreign Intelligence Surveillance Act require a court order to acquire this information. ${ }^{298}$ Again, the Bush administration apparently is violating the law.

\section{New Pen Register and Trap-and-Trace Authority}

A pen register records the outgoing numbers dialed from a particular telephone and a trap-and-trace device records incoming numbers. In Smith v. Maryland, ${ }^{299}$ the Supreme Court held that the Fourth Amendment provided no

294. Id. §1805(a)(3).

295. Anita Ram asastry, Why the Foreign Intelligence Surveillance Act Court Was Right to Rebuke the Justice Department, FINDLAw, Sept. 4, 2002, http://w rit.news.fin dlaw.com/ramasastry/2002 0904 .h tml.

296. Leslie Cauley, NSA has Massive Database of Americans' Phone Calls; 3 Telecoms Help Government Collect Billions of Domestic Records, USA TODAY, May 11, 2006, at 1A; see also Barton Gellman \& Arshad Mohammed, Data on Phone Calls Monitored; Extent of Administration's Domestic Surveillance Decried in Both Parties, WASH. Post, May 12, 2006, at A01; Eric Lichtblau \& Scott Shane, Bush is Pressed Over New Report on Surveillance, N.Y. TIMES, May 12, 2006, at A1.

297. See Smith v. Maryland, 442 U.S. 735 (1979) (holding that for Fourth Amendment purposes there is no reasonable expectation of privacy in the numbers dialed from a particular telephone).

298. See infra notes 299-308.

299. 442 U.S. 735 (1979). 
protection against the use of such law enforcement tools since one had no expectation of privacy in numbers dialed to and from a telephone. The Court held both that a person must know that the telephone company would have access to these numbers and that by voluntarily disclosing them to this third party all privacy expectations were lost. ${ }^{300}$ Consequently, the Fourth Amendment imposed no warrant, probable cause, or even reasonable suspicion requirement for the installation of such devices on particular telephones. Congress responded in 1986, when Title III was amended, by supplying law enforcement with broad-based pen register and trap-and-trace authority requiring only that the government certify that the information was "relevant to an on going criminal investigation." ${ }^{301}$

The PATRIOT Act expands this power in two potentially ominous ways. First, $\S 216$ requires $^{302}$ a judge on certification to "enter an ex parte order authorizing the installation and use of a pen register or trap and trace device anywhere within the United States. . .."303 Prior to the PATRIOT Act, the order was limited to "the jurisdiction of the court." 304 This suffers from all of the infirmities of the nationwide service of search warrants addressed earlier with an additional major difficulty. Before granting a search warrant, courts require that the warrant be supported by an affidavit establishing probable cause-whereas a pen register/trap-and-trace order requires only bare certification that the information sought is relevant to an ongoing criminal investigation. The order can then be issued nationwide without any showing of probable cause or even reasonable suspicion. This is an extremely broad power to record the numbers dialed to and from telephones.

The expanded power does not end there, however. The second major alteration of the 1986 law extends pen register/trap-and-trace authority to e-mail and Internet communications. Section 216 modifies the definitions of "pen register" and "trap and trace device" to mean "a device or process which records or decodes dialing, routing, addressing, or signaling information ....."305 This would include, of course, e-mail addresses and Internet sites. Even though the statute excludes "the contents of any communication, ${ }^{" 306}$ and irrespective of the debate of whether such uncoupling

300. Id. at 743-44.

301. 18 U.S.C. $\S 3123(2000)$.

302. The statute says, "[u]pon an application made under section $3122(a)(1)$, the court shall enter an ex parte order ....”18 U.S.C. §3123(a)(1) (Supp. I 2001) (emphasis added).

303. Id. $\S 3123(\mathrm{a})(1)$ (emphasis added).

304. 18 U.S.C. $\S 3123($ a) $(2000)$.

305. 18 U.S.C. $\$ 3127(3)-(4)$ (Supp. I 2001).

306. Id. 
is technologically feasible, ${ }^{307}$ e-mail routing (on the subject line) and Internet sites reveal substantive information, i.e., content, in a way that telephone numbers do not. Once the suggested inability in this technological context to separate so-called envelope information from content and the temptation to law enforcement to ignore the difference are factored in, ${ }^{308}$ the threat to realistic expectations of electronic communicative privacy is profound. It also is worth emphasizing that the expansion of surveillance under $\S 216$ is not limited to terrorism, but applies to all criminal investigations.

\section{Business Records}

\section{a. Section 215}

Section 215 of the PATRIOT Act, authorizing the government to obtain records and documents, substantially expanded the scope and standard under which such records could formerly be gathered under FISA. ${ }^{309}$ Prior to $\S 215$, a FISA judge could order the production of records from only "a common carrier, public accommodation facility, physical storage facility or vehicle rental facility," ${ }^{310}$ and the government was required to specify in its application that there were "specific and articulable facts giving reason to believe that the person to whom the records pertain is a foreign power or an agent of a foreign power." "311 In other words, reasonable suspicion of the involvement of a foreign power had to be established.

Section 215 expanded access to records in three ways. First, the government ${ }^{312}$ can apply for an order "requiring the production of any tangible things (including books, records, papers, documents and other items) . ..."313 This would include, of course, the much debated library and bookstore records.

307. See Nancy Chang, Ctr. For Constitutional Rights, Silencing Political Dissent 54-55 (2002); Orin S. Kerr, Internet Surveillance Law After the USA Patriot Act: The Big Brother That Isn't, 97 NW. U. L. Rev. 607 (2003); Steven A. Osher, Privacy, Computers and the Patriot Act: The Fourth Amendment Isn't Dead, But No One Will Insure It, 54 FLA. L. REV. 521, 528 (2002); Stephen W. Tountas, Note, Carnivore: Is the Regulation of Wireless Technology a Legally Viable Option to Curtail the Growth of Cybercrime?, 11 WASH. U. J.L. \& POL'Y 351, 372 (2003).

308. See sources cited supra note 307.

309. USA PATRIOT Act $\S 215$.

310. 50 U.S.C. $\S 1862$ (a) $(2000)$.

311. Id. §1862(6)(2)(B).

312. The application for an order is limited to "[the] Director of the Federal Bureau of Investigation or a designee of the Director (whose rank shall be no lower than Assistant Special Agent in Charge) ...." 50 U.S.C. $\$ 1861$ (a) (Supp. I 2001).

313. Id. 
Second, the target is no longer limited to a foreign power, but extends to an investigation to obtain foreign intelligence information ${ }^{314}$ or to protect against international terrorism or clandestine intelligence activities. ${ }^{315}$ Although "investigation of a United States person . . conducted solely upon the basis of activities protected by the First Amendment" is excluded, ${ }^{316}$ it is hardly clear what this entails and is probably meant to apply merely to associational rights. Third, the reasonable suspicion requirement was eliminated. The government needed only to specify that the records are sought for an investigation authorized by the section. ${ }^{317}$ Once this was done, $\S 215$ required the judge to issue the order as requested or as modified; there was no judicial discretion to refuse the order involved. ${ }^{318}$ Also, the authority to issue these

314. Investigations for inform ation concerning "United $S$ tates person[s]" are excluded. Id.
315. Id.
316. Id.
317. Id. $\S 1861(\mathrm{~b})(2)$.
318. Id. $\S 1861$ (c)(1) (Supp. I 2001). The application of the original $\S 215$ to all books, records, papers, documents and other items-things covered by the Fourth Amendment-plus the absence of a probable cause or even reasonable suspicion requirement made it vulnerable to legal challenge. To be sure, the Supreme Court in three narrow categories has permitted investigatory techniques without rea sonable suspicion, but only one has any potential of applying to the authority granted by the PATRIOT Act to obta in records and documents.

The Court has not required reasonable suspicion where they have concluded that there is no search or no seizure, or there is some administrative procedure employed where the needs of law enforcement outweigh the threat to individual privacy interests. See Michigan Dep't of State Police v. Sitz, 496 U.S. 444 (1990); Marshall v. Barlow's Inc., 436 U.S. 307 (1978); United States v. Martinez-Fuerte, 428 U.S. 543 (1976); Cam ara v. Mun. Court of S.F., 387 U.S. 523 (1967); and supra notes 113-23 and a ccom panying text. The latter two clearly do not apply to $\S 215$. The no-seizure cases involve police-citizen encounters in which the Court has concluded that a reasonable person would feel free to leave or otherwise terminate the encounter. The administrative search cases all involve demonstrated governmental need with minimal invasion of privacy where a regular criminal investigation is not involved, e.g., administrative inspections, immigration and DUI checkpoints, and random drug testing.

The only analysis potentially applying to $\S 215$ records acquisitions is the Supreme Court's no search rationale where the Court has concluded that a person bears no expectation of privacy in the items seized. The closest analogues here are garbage left at the curbside for collection, California v. Greenwood, 486 U.S. 35 (1988), phone numbers dialed from a particular telephone, Smith v. Maryland, 442 U.S. 735 (1979), and voluntary communication to someone who discloses the contents of the conversation to the police, United States v. White, 401 U.S. 745 (1971). In all these instances, the Court has concluded that by voluntarily disclosing the item or information to another party, a person as sumes the risk of disclosure and sacrifices whatever expectation of privacy that would exist otherwise. It is conceivable that such an analysis could apply to library records or purchases at a bookstore (if there actually are such records from credit card use or otherwise) under the theory that the information about the checkout or purchase has been voluntarily disclosed. The information conveyed here, however, is the price or location of the book, not one's reading habits or preferences. If this type of exchange were considered to destroy privacy expectations for the latter, then no human interaction could be considered private.

More importantly, many of the records and documents covered by $\S 215$ do not involve any sort of voluntary disclosure. The records are simply compiled by the assembling body or institution, such as 
orders has been expanded beyond judges of the FISA court to United States magistrate judges. ${ }^{319}$ Section 215 also imposes secrecy and gag requirements applicable both to the order issued ${ }^{320}$ and to persons disclosing documents under the order. ${ }^{321}$

The USA PATRIOT Reauthorization and Improvement Act of 2005 adds some restrictions and scales back some of this broad, virtually unrestricted, investigatory authority. First, the authority to request an order for the production of records has been limited to higher ranking Justice Department officials. ${ }^{322}$ Second, real judicial oversight has been reintroduced. A request for an order under $\S 215$ must now include "a statement of facts showing there are reasonable grounds to believe that the tangible things sought are relevant to an authorized investigation, ${ }^{, 323}$ and the judge must find that the application satisfies this requirement before the order is issued. ${ }^{324}$ As significant, a procedure has been added allowing a person receiving an order to challenge its legality. ${ }^{325}$ Also included are a particularity requirement ${ }^{326}$ and procedures to minimize retention and dissemination of the material gathered. ${ }^{327}$ Lastly, an exception to the prohibition on disclosure of receipt of the order has been made for disclosure to "an attorney to obtain legal advice or assistance with respect to the production of things in response to the order." 328 Nonetheless, even with these new restrictions, the $\S 215$ power is broader than a grand jury subpoena. ${ }^{329}$ A grand jury investigation is limited to past conduct, not some speculative inquiry into future crime or attacks. Recipients of grand jury subpoenas can discuss them publicly, and there are strict secrecy requirem ents preventing the government from disclosing or sharing grand jury information. ${ }^{330}$

\footnotetext{
student or medical records. Here, of course, the no privacy expectation/no search rationale fails entirely. Thus, $\S 215$ is constitutionally suspect and may be the first legal casualty in the PATRIOT Act. 


\section{b. Section 505 and National Security Letters (NSL)}

Actually, the government need not rely on a FISA judge's order to acquire business records and documents. Section 505 of the PATRIOT Act authorizes the use of "National Security Letters" to get this information. ${ }^{331}$ Created in the 1970s for espionage and terrorism investigations, the Act transformed these letters into a means of collecting a massive amount of data about individudals not thought to be terrorists or spies. They are issued by FBI field supervisors without the authority of a prosecutor, grand jury or judge. No specific or articulable reasons are necessary. The government need only certify that "the information sought is relevant to an authorized investigation to protect against international terrorism or clandestine intelligence activities." 332 Telephone, transactional, financial, and consumer records are covered by $\S 505 .{ }^{333}$ Thus, it is possible to determine how a person makes and spends money, how he travels, borrows and invests, what he reads, and to whom he communicates on the Internet and by telephone. According to the Washington Post, the FBI now issues over 30,000 national security letters a year, which is a hundred-fold increase over historic practice. ${ }^{334}$

The data collected is retained and kept in electronic files to permit investigations involving "data mining" and "chaining"-attempts to link suspicious activities and persons together. ${ }^{335}$ In this way, the information is used not to detect past criminality, but to generate leads regarding suspected future behavior. As indicated previously, it is thus wholly unlike a grand jury investigation, which focuses on past conduct. Also, witnesses who receive a grand jury subpoena are free to discuss it. The recipient of an NSL is permanently barred from disclosing the letter, ${ }^{336}$ except to an attorney to whom disclosure is made to obtain legal advice or assistance. ${ }^{337}$

A number of industry groups, including the U.S. Chamber of Commerce, sent a letter to Congress in October 2005, urging reformation of both $\S 505$ and $\S 215$ to protect the privacy rights of both Americans and foreign citizens, and to prevent the expensive and time-consuming burden of complying with

331. USA PATRIOT Act $\S 505$.

332. Id. $\S 505(\mathrm{a})(3)(\mathrm{B})$.

333. Id. $\S 505$.

334. Barton Gellman, The FBI's Secret Scrutiny; In Hunt for Terrorists, Bureau Examines Records of Ordinary Americans, W ASH. POST, Nov. 6, 2005, at A01.

335. Id.

336. Reauthorization Act $\S 116(a)$.

337. This was a change made by the 2006 Reauthorization Act. 
government requests for information. ${ }^{338}$ In response, Con gress modified $\S 505$ in the 2006 Reauthorization Act, providing the recipient of the order with the opportunity to challenge in United States district court both the order itself and the nondisclosure requirement. A district judge may now set aside the request "if compliance would be unreasonable, oppressive, or otherwise unlaw ful," 339 and "the court may modify or set aside . . a nondisclosure requirement if it finds that there is no reason to believe that disclosure may endanger the national security of the United States, interfere with a criminal, counterterrorism, or counterintelligence investigation, interfere with diplomatic relations, or endanger the life or physical safety of any person. ${ }^{340}$ The recent reauthorization also makes clear that libraries, when functioning in their traditional roles, including that of providing Internet access, cannot be the target of NSLs. ${ }^{341}$ Before the reauthorization, two federal district courts had ruled that $\S 505$ violates the First and Fourth Amendments. ${ }^{342}$

\section{CONCLUSION}

I have discussed the Supreme Court's Fourth Amendment decisions during the War on Drugs and our reaction to terrorism not so much to critique the law, but to show a progressive phenomenon during the last quarter of the twentieth century into the twenty-first century. This phenomenon I have termed "the blueing of America" for the country's list toward permissive police investigatory practices and the concomitant loss in privacy rights it entails. The trend can be embraced, either in terms of a law and order mentality or as necessary for national security, but it cannot be denied.

As I have tried to show, the phenomenon has been created by the temporal interaction of first the War on Drugs and second the War on Terror. What needs to be emphasized, however, is that this bent toward law enforcement, and the resulting decline in civil liberties, did not begin with the War on Terror, but started thirty years ago in the United States Supreme Court. With the advent of congressional action (and presumably the judicial response) to the acts of terrorism, this is no longer a trend but is now a development. It

338. Business Groups Ask Congress to Add Checks to PATRIOT Act, 78 CRIM. L. REP. (BNA) 70-71 (2005) [hereinafter Business Groups].

339. Reauthorization Act $\$ 115(2)$.

340. Id.

341. USA PATR IOT A ct Additional Reauthorizing Amendments Act of 2006, § 5, Pub. L. 109-178, 120 Stat. 278 (amending 18 U.S.C. $\$ 2709$ ).

342. Business Groups, supra note 338, at 70-71; Gellman, supra note 334. 
eased into existence methodically at first and then rapidly after September 11, 2001. It has the capacity to affect us all.

Of course, as in the case of other repressive episodes, it falls most heavily on those outside the power structure, in America notably the black and the poor. These are the folks who are generally on the periphery of the culture where it intersects with the criminal justice system. It is thus possible for the mainstream culture to either miss or ignore the overall loss in civil liberties until its members themselves are individually impacted. The Supreme Court's Fourth Amendment decisions probably did this only sporadically. The PATRIOT Act has struck a different chord, both because it has gained notoriety in the media and because its provisions have the potential to impact a broader audience. The War on Terror may have done what the War on Drugs did not do-force us to take collective notice in the decline of privacy rights and civil liberties over the past quarter century. 